\title{
Removal of micropollutants during biological phosphorus removal: Impact of redox conditions in MBBR
}

Torresi, Elena; Tang, Kai; Deng, Jie; Sund, Christina; Smets, Barth F.; Christensson, Magnus; Andersen, Henrik Rasmus

Published in:

Science of the Total Environment

Link to article, DOI:

10.1016/j.scitotenv.2019.01.283

Publication date:

2019

Document Version

Peer reviewed version

Link back to DTU Orbit

Citation (APA):

Torresi, E., Tang, K., Deng, J., Sund, C., Smets, B. F., Christensson, M., \& Andersen, H. R. (2019). Removal of micropollutants during biological phosphorus removal: Impact of redox conditions in MBBR. Science of the Total Environment, 663, 496-506. https://doi.org/10.1016/j.scitotenv.2019.01.283

\section{General rights}

Copyright and moral rights for the publications made accessible in the public portal are retained by the authors and/or other copyright owners and it is a condition of accessing publications that users recognise and abide by the legal requirements associated with these rights.

- Users may download and print one copy of any publication from the public portal for the purpose of private study or research.

- You may not further distribute the material or use it for any profit-making activity or commercial gain

- You may freely distribute the URL identifying the publication in the public portal 


\section{Accepted Manuscript}

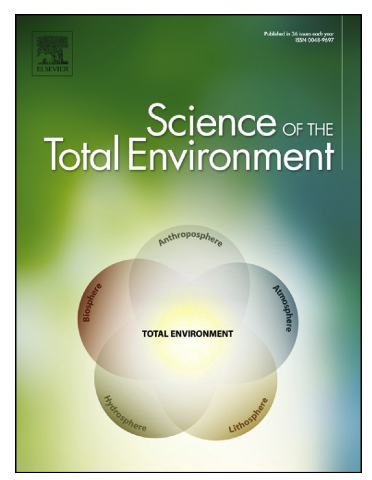

Elena Torresi, Kai Tang, Jie Deng, Christina Sund, Barth F. Smets, Magnus Christensson, Henrik R. Andersen

Removal of micropollutants during biological phosphorus removal: Impact of redox conditions in MBBR

PII:

S0048-9697(19)30326-2

DOI: https://doi.org/10.1016/j.scitotenv.2019.01.283

Reference: STOTEN 30597

To appear in: Science of the Total Environment

Received date: 26 November 2018

Revised date: 20 January 2019

Accepted date:

21 January 2019

Please cite this article as: E. Torresi, K. Tang, J. Deng, et al., Removal of micropollutants during biological phosphorus removal: Impact of redox conditions in MBBR, Science of the Total Environment, https://doi.org/10.1016/j.scitotenv.2019.01.283

This is a PDF file of an unedited manuscript that has been accepted for publication. As a service to our customers we are providing this early version of the manuscript. The manuscript will undergo copyediting, typesetting, and review of the resulting proof before it is published in its final form. Please note that during the production process errors may be discovered which could affect the content, and all legal disclaimers that apply to the journal pertain. 


\section{Removal of micropollutants during}

\section{biological phosphorus removal: impact of redox conditions in MBBR}

Elena Torresi ${ }^{1,2, *}$, Kai Tang ${ }^{1}$, Jie Deng ${ }^{1}$, Christina Sund ${ }^{3}$, Barth F. Smets ${ }^{1}$, Magnus Christensson $^{2}$, Henrik R. Andersen ${ }^{1}$

${ }^{1}$ DTU Environment, Technical University of Denmark, Bygningstorvet B115, 2800 Kongens Lyngby, Denmark

${ }^{2}$ Veolia Water Technologies AB, AnoxKaldnes, Klosterängsvägen 11A, SE-226 47 Lund, Sweden

${ }^{3}$ Veolia Water Technologies - Krüger A/S, Gladsaxevej 363, DK 2860 Søborg, Denmark

*Corresponding authors: elena.torresi@ anoxkaldnes.com 


\section{Abstract}

Further biological polishing of micropollutants in WWTP effluents is limited by the lack of available carbon for cometabolic degradation. Metabolism of polyhydroxyalkanoates (PHAs) stored intracellularly during enhanced biological phosphorus removal (EBPR) could serve as carbon source for post-denitrification and micropollutant cometabolism.

The removal of nine micropollutants (i.e., pharmaceuticals and corrosion inhibitors) was investigated by using Moving Bed Biofilm Reactors (MBBRs), selecting phosphorus (PAO) or glycogen (GAO) accumulating organisms under different redox conditions. Three laboratory-scale MBBRs were operated in sequencing-batch mode under cyclical anaerobic and aerobic/anoxic conditions for

phosphorus removal. Batch experiments were performed to evaluate the biodegradation potential of micropollutants along with the utilization of internally stored PHA. Experiments showed that aerobic PAO were able to efficiently remove most of the targeted micropollutants. The removal of benzotriazole, 5-methyl-1H-benzotriazole, carbamazepine, ketoprofen and diclofenac occurred simultaneously to phosphorus uptake and terminated when phosphorus was no longer available. Denitrifying PAO and aerobic GAO exhibited lower removal of micropollutants than aerobic PAO. Degradation profiles of stored PHA suggested a diverse utilization of the different fractions of PHA for phosphorus and micropollutant removal, with PHV (poly 3-hydroxyvalerate) most likely used for the cometabolism of targeted micropollutants. 


\section{Introduction}

In the last decades, micropollutants such as pharmaceuticals, personal care products, household and industrial chemicals have been frequently detected in the aquatic environment (Daughton and Ternes, 1999; Reemtsma et al., 2006). Although they are typically found in effluents of municipal wastewater treatment plants (WWTPs) in concentration of $n g \mathrm{~L}^{-1}$ to $\mu \mathrm{g} \mathrm{L}^{-1}$ (Ternes, 1998), effects of several micropollutants on aquatic organisms have been observed (Garric et al.,1996; Hoeger et al., 2005). The widespread occurrence of micropollutants indicates that conventional WWTPs are unable to completely remove these substances (Reemtsma et al., 2006). Currently, upgrading of conventional WWTP to improve removal of micropollutants from effluent wastewater mostly consider physicalchemical treatment, such as activated carbon or ozonation (Knopp et al., 2016; Stoquart et al., 2016). However, high costs associated with ozone treatment (Knopp et al., 2016), activated carbon regeneration and the possibility of the formation of oxidation products with equal or greater toxicity than the parent chemical (Benner et al., 2013), make biological treatment a desired alternative for removal of micropollutants.

Recent studies have proposed biofilm systems, e.g., MBBR, as a promising alternative to conventional activated sludge systems (CAS) with respect to the attenuation of micropollutants via biological treatment (Escolà Casas et al., 2015; Falås et al., 2016, 2012; Hapeshi et al., 2013; Torresi et al., 2016, 2017a). In MBBR, biofilms grow on specifically designed plastic carriers, which are suspended and retained in the system (Ødegaard, 1999).

Recently, Tang et al., (2017) investigated MBBR as a polishing technology for effluent wastewater, where an intermitting feeding strategy with influent wastewater (recirculated from primary clarification) was able to sustain the biomass growth, "boosting" the activity of the MBBR towards the 
removal of a number of micropollutants (e.g., diclofenac). Indeed, tertiary biological treatment of micropollutants is limited by different factors such (i) the low concentration of micropollutants in the effluent wastewater which does not allow biomass growth, and (ii) the lack of carbon and nutrients in effluent wastewater necessary to support primary metabolisms of the micropollutant degrader organisms, in case cometabolism drives micropollutants degradation. Therefore, new strategies are needed to optimize tertiary biological treatment, and to provide an available carbon source for the primary metabolism, which drives the biodegradation of micropollutants even at the last stages of WWTP.

Methanol and ethanol are commonly used carbon sources that are added for post-denitrification in WWTP (Santos et al., 2001). However, in recent years, other solid substrates such as polyhydroxyalkanoates, PHAs (intracellularly stored), have been proposed for such purpose, as an alternative to soluble added substrates (Coats et al., 2011; Krasnits et al., 2013).

PHA are biopolymers that can be accumulated into the biomass during transient operation regarding carbon supply and redox conditions, as happens for example, during enhanced biological phosphorus removal (EBPR) (Dias et al., 2006). During an anaerobic phase, organic acids present in the wastewater, such as volatile fatty acids (VFA) are taken up and stored intracellularly as PHA by phosphate accumulating organisms, PAOs, by using the energy obtained from cleavage of previously stored polyphosphate and glycogen. In the subsequent aerobic and carbon poor conditions, PHA is used as carbon and energy source by the aerobic PAO for cell growth and to fuel the uptake and storage of polyphosphate and glycogen. When anaerobic conditions are followed by anoxic conditions, PHA can also support as carbon and energy source by the denitrifying PAOs (DPAOs) (Coats et al., 2011). During EBPR operation conditions, another group of bacteria named GAOs (glycogen- accumulating organisms) can also store PHA and compete with the PAO for the uptake of VFA, but without 
removing any phosphate from wastewater, as their main energy source used for substrate uptake is glycogen (Lopez-Vazquez et al., 2009). As intracellular stored polymers (by both PAOs and GAOs), PHAs are easily decomposed and could be used as carbon source for phosphorus removal (Coats et al., 2011).

Only few studies have investigated the removal of micropollutants in systems performing EBPR. Ogunlaja and Parker (2018) studied the potential of PAO for removal of trimethoprim in a pilot-scale during biological nitrogen removal (BNR). They suggested a contribution of PAO to the removal of trimethoprim, although with lower biotransformation kinetics than other microbial groups (i.e., nitrifying and ordinary heterotrophic bacteria). Muz et al. (2014) studied the removal of six selected endocrine disrupting compounds in a lab-scale anaerobic-aerobic sequencing batch reactor (SBR) that exhibited more than $60 \%$ removal of most of the compounds, with exception of carbamazepine.

However, while these few studies gave an indication of PAO activity towards the removal of few micropollutants, no current evidences exist on the PAO and GAO activity for a wide range of micropollutants under different redox conditions.

Specific objectives of this research were to: (i) assess and compare the potential of aerobic PAO, anoxic DPAO and GAO enrichments for the removal of nine frequently detected micropollutants (two corrosion inhibitors and seven pharmaceuticals); and (ii) to investigate how PHA (3-hydroxybutyrate (3-PHB) and 3-hydroxyvalerate (3-PHV)) depletion profiles aligned with the micropollutants degradation profiles. Overall, this study was meant as "proof-of-concept" of a new operation of MBBR for tertiary treatment of micropollutants (based on a Swedish patent and previously discussed in Tang et al. (2017)). The new concept is currently tested in a pilot MBBR treating effluent municipal wastewater in a Danish WWTP. 


\section{Material and methods}

\subsection{Description of the sequencing batch MBBR system (long term-operation)}

Three laboratory-scale MBBRs ( $2 \mathrm{~L}$ of operating volume in glass reactor) were operated in sequencingbatch mode for enhanced biological phosphorus removal. $\mathrm{R} 1_{\mathrm{PAO}}$ and $\mathrm{R} 2_{\mathrm{APAO}}$ were operated under cyclical anaerobic-aerobic conditions, while $\mathrm{R} 3_{\mathrm{DPAO}}$ under cyclical anaerobic-anoxic conditions.

Each cycle consisted of two phases: (i) phase 1 was under anaerobic conditions that lasted 1 hour (reaction time) and it was similar in all three reactors; (ii) phase 2 was under aerobic conditions for $\mathrm{R} 1_{\mathrm{PAO}}$ and $\mathrm{R} 2_{\mathrm{APAO}}$, anoxic conditions in $\mathrm{R} 3_{\mathrm{DPAO}}$ and it lasted 6 hours (reaction time) in all three reactors (Fig 1). Overall, the SBR operation for the three reactors consisted of the following phases: (i) fill (6 min), (ii) react under anaerobic conditions with VFA availability (1 hour), (iii) drain (100\%, 12 $\mathrm{min}$ ), (iv) fill (6 min), (v) react under aerobic $\left(\mathrm{R} 1_{\mathrm{PAO}}\right.$ and $\left.\mathrm{R} 2_{\mathrm{APAO}}\right)$ or anoxic ( $\left.\mathrm{R} 3_{\mathrm{DPAO}}\right)$ conditions (no VFA present) (6 hours), (vi) drain (100\%, $12 \mathrm{~min})$. Thus, a cycle lasted in total 7.6 hours, including reaction time $(7 \mathrm{~h})$ and draining/filling time $(0.6 \mathrm{~h})$. A detailed explanation of the operation conditions was reported in Table S1 of the Supplementary information.

The duration of the anaerobic phase was set to be within the recommended 1-2 $\mathrm{h}$ contact period for biological phosphorus removal (Wang et al., 2011), while the aerobic (for $\mathrm{R} 1_{\mathrm{PAO}}$ and $\mathrm{R} 2_{\mathrm{APAO}}$ ) and anoxic ( $3_{\text {DPAO }}$ ) phases were kept long enough to provide sufficient contact time for the dissolved micropollutants and the biomass. The phases were automatically controlled by using a programmable power strip (EnerGenie power manager). A $100 \%$ drain between phases minimized the presence of dissolved organic carbon during phase 2 and the proliferation of other heterotrophic bacteria rather than PAO. For the three reactors and during both phases, a synthetic medium was used and consisted of: a 
mixture of $\mathrm{K}_{2} \mathrm{HPO}_{4}$ and $\mathrm{KH}_{2} \mathrm{PO}_{4}\left(56 \%\right.$ and $44 \%$, respectively) to a final concentration of $30 \mathrm{mg} \mathrm{L}^{-1}$ of $\mathrm{PO}_{4}-\mathrm{P}$ and $20 \mathrm{mg} \mathrm{L}^{-1}$ of potassium, $\mathrm{NH}_{4} \mathrm{Cl}$ to a final concentration of $5 \mathrm{mg} \mathrm{L}^{-1}$ of $\mathrm{NH}_{4}-\mathrm{N}$, $\mathrm{MgSO}_{4} * 7 \mathrm{H}_{2} \mathrm{O}$ to a final concentration of $15 \mathrm{mg} \mathrm{L}^{-1}$ of $\mathrm{Mg}$ and $\mathrm{CaCl}_{2} * 2 \mathrm{H}_{2} \mathrm{O}$ to a final concentration of $40 \mathrm{mg} \mathrm{L}^{-1}$ of $\mathrm{Ca}^{+}$, and additional trace elements (section 1 in $\mathrm{SI}$ ). High concentration of $\mathrm{PO}_{4}-\mathrm{P}$ was chosen for optimal conditions for PAO growth.

At the beginning of phase 1, an additional solution of synthetic VFA was added to an initial concentration of $250 \mathrm{mg} \mathrm{L}^{-1}$ of COD to ensure sufficient availability of carbon source for the anaerobic metabolism of the EBPR system. The VFA solution consisted of a mixture (mgCOD based) of sodium acetate $\left(84 \%\right.$ of, $\left.0.31 \mathrm{~g} \mathrm{~L}^{-1}\right)$ and propionic acid $\left(15 \%, 0.065 \mathrm{~m} \mathrm{~L}^{-1}\right)$, peptone and yeast $\left(1 \%, 0.05 \mathrm{~g} \mathrm{~L}^{-1}\right.$ respectively).

Sparging of nitrogen gas was used during phase 1 to provide mixing and anaerobic conditions (DO < $0.2 \pm 0.05 \mathrm{mg} \mathrm{L}^{-1}$ ) for all three reactors and mixing of the carriers for $\mathrm{R} 2 \mathrm{APAO}$ under phase 2 . Aeration

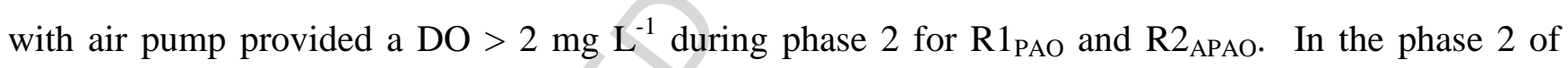
R3 3 DPAO, a solution of potassium nitrate $\left(\mathrm{KNO}_{3}\right)$ was additionally spiked to reach an initial concentration of $100 \mathrm{mg} \mathrm{L}^{-1}$ of $\mathrm{NO}_{3}-\mathrm{N}$. High concentration of nitrate was chosen to ensure a stoichiometric excess of electron acceptor during the anoxic phase.

Temperature was set at $2{ }^{\circ} \mathrm{C}$ using a thermostat bath for $\mathrm{R} 1_{\mathrm{PAO}}$ while $\mathrm{R} 2_{\mathrm{APAO}}$ and $\mathrm{R} 3_{\mathrm{DPAO}}$ were operated at ambient temperature $\left(20 \pm 1.5^{\circ} \mathrm{C}\right)$. $\mathrm{pH}$ was kept at $7.5 \pm 0.5$ by periodic addiction of sodium hydroxide $\left(16 \mathrm{mg} \mathrm{L}^{-1}\right)$ and $\mathrm{HCL}\left(10 \mathrm{mg} \mathrm{L}^{-1}\right)$. The number of carriers used in each reactor was 180,150 and 160 pieces for $\mathrm{R} 1_{\mathrm{PAO}}, \mathrm{R} 2_{\mathrm{APAO}}$ and $\mathrm{R} 3_{\mathrm{DPAO}}$ respectively, corresponding to an estimated exposed biofilm area of $0.1 \mathrm{~m}^{2} \mathrm{~L}^{-1}$ (Piculell, 2016).

The inoculum biofilm carriers for the three MBBR consisted of AnoxK ${ }^{\mathrm{TM}} \mathrm{Z}-400$ (Veolia Water Technologies) from two different existing pilot plants. The AnoxK ${ }^{\mathrm{TM}} \mathrm{Z}-400$ carriers allow for the 
development of biofilm with a maximum thickness of $400 \mu \mathrm{m}$. Inoculum 1 used for $\mathrm{R} 1_{\mathrm{PAO}}$ derives from a pilot plant operated with municipal wastewater for EBPR. Inoculum 2 used for both $\mathrm{R} 2_{\mathrm{APAO}}$ and $\mathrm{R} 3_{\mathrm{DPAO}}$ was taken from a pilot plant operated with municipal influent wastewater for COD and nitrogen removal. The difference between the two aerobic $\mathrm{MBBR} R 1_{\mathrm{PAO}}$ and $\mathrm{R} 2_{\mathrm{APAO}}$ was therefore only the biomass inoculum. $\mathrm{R} 1_{\mathrm{PAO}}$ was operated for approximately 150 days, while $\mathrm{R} 2_{\mathrm{APAO}}$ and $\mathrm{R} 3_{\mathrm{DPAO}}$ for 80 days.

To monitor the biomass activity during the long term SBR operation of the three reactors, samples for analysis of COD and $\mathrm{PO}_{4}-\mathrm{P}$ were taken during phase 1 (5 samples over $1 \mathrm{~h}$ of operation at $0,15,30,45$, $60 \mathrm{~min}$ ) and only for $\mathrm{PO}_{4}-\mathrm{P}$ during phase 2 ( 7 samples over 6 hours of operation at $0,0.5,1,1.5,2,4,6$ h). 


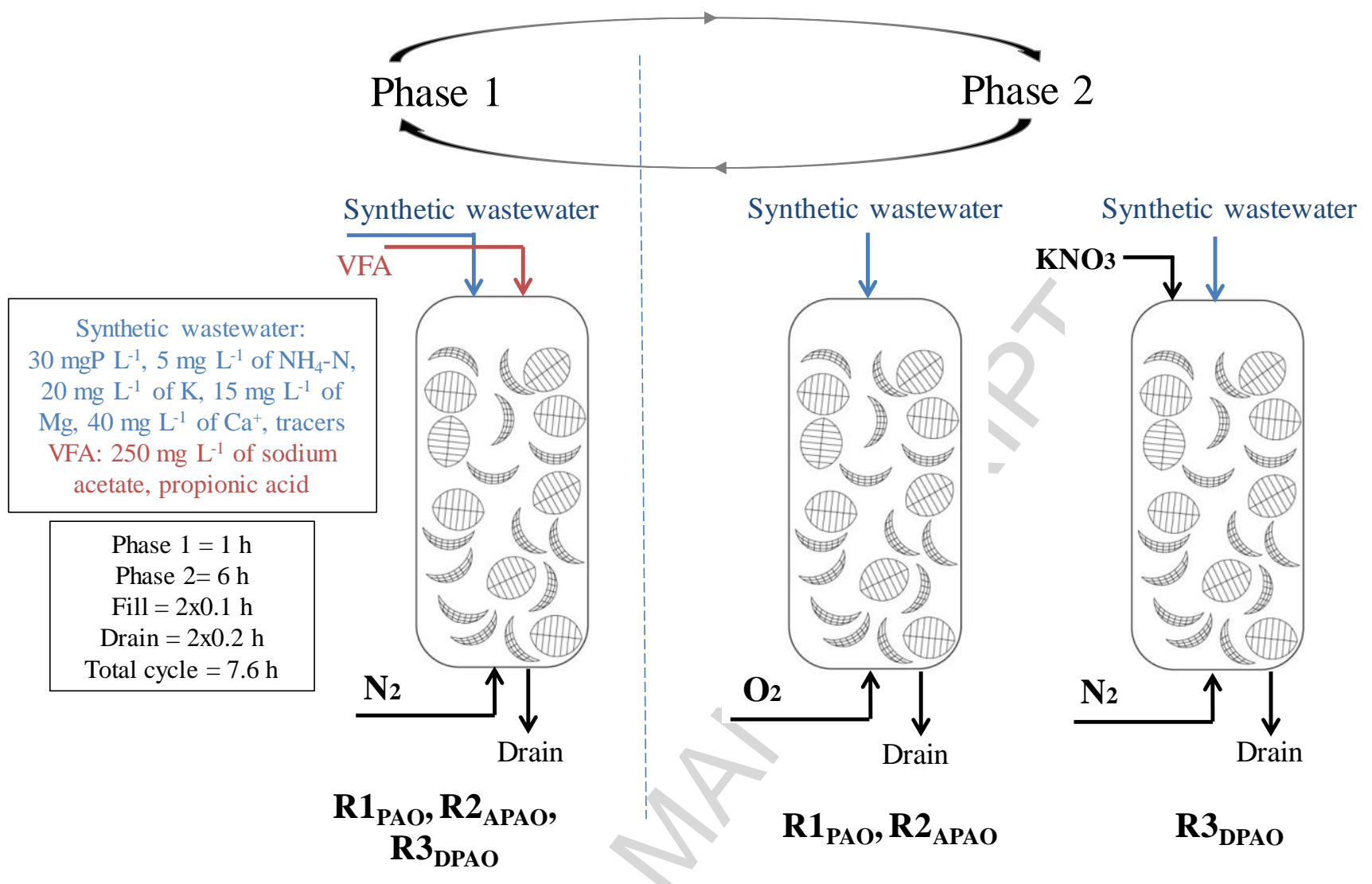

Figure 1. Schematic representation of the three SBMBBRs. Phase 1 was anaerobic for all three reactors. During phase $2, \mathrm{R} 1_{\mathrm{PAO}}$ and $\mathrm{R} 2_{\mathrm{APAO}}$ were kept under aerobic conditions, while $\mathrm{R} 3_{\mathrm{DPAO}}$ under anoxic conditions. The difference between the two aerobic MBBR R $1_{\mathrm{PAO}}$ and $\mathrm{R} 2_{\mathrm{APAO}}$ was the biomass inoculum.

\subsection{Chemicals}

Nine compounds were studied, that can be divided in two groups: (i) two corrosion inhibitors, i.e., benzotriazole and 5-methyl-1H-benzotriazole and (ii) seven pharmaceuticals, i.e., a) analgesic (diclofenac and carbamazepine); b) anti-inflammatory (ibuprofen and ketoprofen); c) fibrate (gemfibrozil and bezafibrate) and d) herbicide (clofibric acid). Compounds were obtained from Sigma- 
Aldrich (Munich, Germany) and they were chosen according to the Swiss strategy for micropollutants as well as the most detecteted pharmaceuticals in effluents of WWTP (Margot et al., 2015). Formic acid and HPLC-gradient grade methanol were purchased from Sigma-Aldrich (Schnelldorf, Germany). The chemical properties of the nine compounds are shown in the Table S2 in SI. Chemical properties for each compound were retrieved using ACD/Labs predictions and the database Molinisticts, PubChem.

\subsection{Batch experiments for micropollutants}

Batch experiments for the three reactors were performed to assess the removal of the nine micropollutants in the three MBBRs during phosphorus removal. The batch experiments were performed when a stable performance in COD and phosphorus removal was observed.

\subsubsection{Batch experiment for $R 1_{P A O}$ reactor for biotic removal}

For reactor $\mathrm{R} 1_{\mathrm{PAO}}$, two batch experiments at two different times of operation were performed: after approximately 30 (Batch 1) and 150 days (Batch 2) of operation. A change in performance in phosphorus release and uptake was observed after 100 days of operation that suggested a shift of microbial community from PAO to GAO (discussed in section 3.1).

For both batch experiments, phase 1 was performed to achieve PHA accumulation under anaerobic conditions at same initial feeding conditions (VFA availability) as of the long term operation. In this phase (lasting 1 hour), only COD and phosphorus but not micropollutants were monitored, by collection of 5 samples at $0,15,30,45,60 \mathrm{~min}$. After 1 hours of operation, the feed water was drained and 60 carriers $(11 \%$ filling ration) were transferred into new glass reactors of $1 \mathrm{~L}$. Micropollutants 
biodegradation was instead monitored during phase 2 under aerobic conditions over 24 hours (11 samples at $0,0.3,0.5,1,2,3,4,6,20,22,24 \mathrm{~h}$ for $\left.\mathrm{R} 1_{\mathrm{PAO}}\right)$. Simultaneously to the micropollutants sampling, samples for analysis of phosphorus were taken. In Batch 1, during phase 2, two different conditions were tested: (i) aerobic conditions with initial targeted $\mathrm{PO}_{4}-\mathrm{P}$ concentration of $8 \mathrm{mg} \mathrm{L}^{-1}$ $\left(\mathrm{R} 1_{\mathrm{PAO}}\left(\right.\right.$ lowP)) and (ii) aerobic condition with initial concentration of $30 \mathrm{mg} \mathrm{L}^{-1}\left(\mathrm{R} 1_{\mathrm{PAO}}(\right.$ highP)). This was done to investigate if there was a notable enhancement or inhibition of the primary substrate (phosphorus) on the cometabolic activity of the PAO community, by using low and high strength wastewater. In Batch 2, when GAO community most likely dominated PAO in the community, only high concentration of phosphorus $\left(30 \mathrm{mg} \mathrm{L}^{-1}\right)$ as used during long term operation was tested $\left(\mathrm{R} 1_{\mathrm{GAO}}\right)$.

For both batch experiments, reference substances (dissolved in methanol in a stock solution of $100 \mathrm{mg}$ $\mathrm{L}^{-1}$ ) were first spiked into a glass beaker and the methanol was let evaporate. Subsequently, the substances were re-dissolved in the synthetic wastewater (two different solutions for high and low P as described previously) and used for the batch experiments. Reference substances were spiked to an initial concentration of $50 \mu \mathrm{g} \mathrm{L}{ }^{-1}$.

\subsubsection{Batch experiment for $R 2_{A P A O}$ and $R 3_{D P A O}$ reactors for biotic removal}

Batch experiments for $\mathrm{R} 2_{\mathrm{APAO}}$ and $\mathrm{R} 3_{\mathrm{DPAO}}$ were performed similarly as described for $\mathrm{R} 1_{\mathrm{PAO}}$. After 1 hour under anaerobic conditions and with VFA availability, the reactors were drained and 70 carriers (14\% filling) for each reactor were transferred into a new glass reactor $(1 \mathrm{~L})$. As for $\mathrm{R} 1_{\mathrm{PAO}}$, micropollutants were first spiked in a glass beaker and, once the methanol was evaporated, the mix was re-suspended in the new synthetic feed. In the batch for $\mathrm{R} 2_{\mathrm{APAO}}$ and $\mathrm{R} 3_{\mathrm{DPAO}}$, only the synthetic feed with a phosphorus concentration of $30 \mathrm{mgP} \mathrm{L}^{-1}$ was used, as the main objective of this test was to investigate the different metabolism of aerobic and denitrifying PAO, rather than the effect of primary substrate on the cometabolism of micropollutants. Therefore, similar concentration of PO4-P as used 
during "long term operation" of the MBBR was chosen. Additionally, for R3 $3_{\mathrm{DPAO}}$ a spiking of $\mathrm{KNO}_{3}$ to an initial concentration of $\mathrm{NO}_{3}-\mathrm{N}$ of $100 \mathrm{mg} \mathrm{L}^{-1}$ was used to maintain anoxic conditions. The second phase (aerobic $\mathrm{R} 2_{\mathrm{APAO}}$ and anoxic $\mathrm{R} 3_{\mathrm{DPAO}}$ ) was set to 24 hours and samples for analysis of micropollutants were taken at regular intervals $(12$ samples at $0,0.3,0.5,1,2,3,4,6,9,12,21,24 \mathrm{~h}$ for $\mathrm{R} 2 \mathrm{APAO}$ and $\left.\mathrm{R} 3_{\mathrm{DPAO}}\right)$. Simultaneously to the micropollutants sampling, samples for analysis of phosphorus were taken. Bubble aeration was used in $\mathrm{R} 2_{\mathrm{APAO}}$ for mixing the carriers and to reach a $\mathrm{DO}$ concentration of $7 \pm 0.5 \mathrm{mg} \mathrm{L}^{-1}$. Nitrogen sparging was used for mixing of carriers in $\mathrm{R} 3_{\mathrm{DPAO}}$ to reach a DO concentration lower than $0.5 \mathrm{mg} \mathrm{L}^{-1}$.

\subsubsection{Batch experiment for sorption of micropollutants to biomass}

Batch experiments for sorption were also performed with biomass from $\mathrm{R} 2_{\mathrm{APAO}}$ and $\mathrm{R} 3_{\mathrm{DPAO}}$ to estimate single values of sorption coefficient $\mathrm{K}_{\mathrm{d} \text {,eq }}\left(\mathrm{L} \mathrm{g}^{-1}\right)$. Batch experiments were performed in $0.5 \mathrm{~L}$ glass beaker with the synthetic wastewater (as described previously for the biotic batch experiment) spiked with reference substances (to a concentration of $50 \mu \mathrm{g} \mathrm{L}^{-1}$ for each compound). Carriers (30 for each reactor) were used to reach a biomass concentration of 0.6 and $0.7 \mathrm{gVSS} \mathrm{L}^{-1}$ for $\mathrm{R} 2_{\mathrm{APAO}}$ and $\mathrm{R} 3_{\mathrm{DPAO}}$ respectively and the carriers were mixed by sparging air. Biomass was inhibited using sodium azide (initial concentration of $\left.0.2 \mathrm{mg} \mathrm{L}^{-1}\right)$. Sorption coefficient $\mathrm{K}_{\mathrm{d} \text {,eq }}\left(\mathrm{L} \mathrm{g}^{-1}\right)$, were calculated according to the formula:

$K_{d, e q}=\frac{C_{L, 0}-C_{L, e q}}{C_{L, e q} X_{\text {biomass }}}$

Where $\mathrm{C}_{\mathrm{L}, 0}$ is the initial measured dissolved concentration of micropollutant, $\mathrm{C}_{\mathrm{L}, \mathrm{eq}}$ is 'asymptotic' concentration at equilibrium estimated by fitting measured concentration profiles in batch sorption experiments with a first-order decay equation, as previously used in Torresi et al. (2017b). $\mathrm{X}_{\text {biomass }}$ is 
the biomass concentration in the reactor. Estimated $\mathrm{K}_{\mathrm{d} \text {,eq }}$ does not account for biofilm porosity and mass transfer into pores.

\subsubsection{Batch experiment for other abiotic removal of micropollutants (control)}

The experiment for abiotic removal was divided into two parts as applied previously (Torresi et al., 2016): (i) without plastic carriers and using only synthetic wastewater spiked with the references substances to asses abiotic degradation and sorption onto glass walls, and (ii) with new carriers added to synthetic wastewater to investigate sorption onto plastic carriers. The abiotic experiment was performed at each batch experiment performed for biotic removal of micropollutants.

\subsection{Quantification of micropollutants}

During batch experiment, at each sampling time, $3 \mathrm{~mL}$ of sample was filtered with a syringe filter and transferred to a glass vial. $0.8 \mathrm{~mL}$ acetonitrile was immediately added into the filtered sample to stop further bioactivity. All samples were preserved at $-20^{\circ} \mathrm{C}$ in a freezer before analysis by HPLC-MS/MS. For analysis, the samples were taken from the freezer and left to reach room temperature. $900 \mu \mathrm{L}$ of each sample was transferred into a HPLC vial and $100 \mu \mathrm{L}$ of internal standard solution consisting of mecoprop and atrazine was afterwards added into the HPLC vial. Lastly, $100 \mu \mathrm{L}$ of sample from the HPLC vial was injected and analysed by HPLC-MS/MS. Further information regarding HPLC-MS/MS are reported in section 2 in SI. The range of limit of quantification (LOQ) for targeted micropollutants was from 0.05 to $10 \mu \mathrm{g} / \mathrm{L}$ and overall $98 \%$ of the theoretical concentration was recovered. 


\subsection{Analytical methods}

Samples taken for analysis of conventional pollutants (soluble COD, $\mathrm{PO}_{4}-\mathrm{P}, \mathrm{NO}_{3}-\mathrm{N}, \mathrm{NO}_{2}-\mathrm{N}$ ) were filtered through $0.45 \mu \mathrm{m}$ glass fiber filters (Sartorius, Göttingen, Germany). Hach Lange kits (LCK 339, LCK 341, LCK 349 and LCK 214) were used and samples were analyzed using a spectrophotometer (Hach Lange DR2800).

Biomass PHA content was determined by Gas Chromatography (GC) with Flame-Ionization Detection (GC-FID) according to the method described in Wang et al., 2017. Firstly, biomass was detached by the use of sterile brush and DI water, collected in Eppendorf tube $(2 \mathrm{ml})$ and samples were kept at -20 ${ }^{\circ} \mathrm{C}$ in a freezer until further analysis. Prior to the analyses, collected biomass from carriers was freezedried for 24 hours. Briefly, dried PHA-rich biomass samples were digested at $100{ }^{\circ} \mathrm{C}$ in $2 \mathrm{~mL}$ each of acidified methanol (20\% sulfuric acid $\mathrm{v} / \mathrm{v})$ and $1 \mathrm{~mL}$ of chloroform containing an exact amount of heptadecane (HD) (approximately $1 \mathrm{~g} \mathrm{~L}^{-1}$ ) as internal standard. Two $\mu \mathrm{L}$ of sample were injected in a gas chromatographer equipped with a FID detector and a column $(60 \mathrm{~m}, 0.53 \mathrm{~mm}$ internal diameter, 1 $\mu \mathrm{m}$ film thickness) coupled with a guard-column (0.32 $\mathrm{mm}$ internal diameter). Samples were analysed using helium as a carrier gas, at constant pressure (14.5 psi), and initial temperature of injection of $280^{\circ} \mathrm{C}$. The main two measured compositions of PHA were 3-hydroxybutyrate (3-PHB) polymer and 3hydroxyvalerate (3-PHV) copolymer. The compounds were confirmed by retention time and mass spectral matching with known PHA standards (a commercial co-polymer of PHB-PHV (88:12 molar)) and quantified based on the internal standard.

The biomass concentrations as TAS (total attached solid) was measured as difference in weight of a clean aluminium plate containing the biomass of 3 carriers (detached from carriers by using DI water 
and a sterile brush) and set in at $105{ }^{\circ} \mathrm{C}$ for $>24 \mathrm{~h}$. VAS (volatile attached solids) were subsequently measured by setting the aluminium plate at $510{ }^{\circ} \mathrm{C}$ for $15 \mathrm{~min}$ and measuring the difference in weight.

\subsection{Removal efficiency, rates and kinetics estimation}

$\mathrm{COD}$ removal rates, $\mathrm{PO}_{4}-\mathrm{P}$ release and removal rates were calculated by liner regression of soluble COD and soluble $\mathrm{PO}_{4}-\mathrm{P}$, respectively, under non limiting condition $\left(\mathrm{COD}>100 \mathrm{mg} \mathrm{L}{ }^{-1}, \mathrm{PO}_{4}-\mathrm{P}>2-20\right.$ $\mathrm{mg} \mathrm{L}^{-1}$ for $\mathrm{R}_{1 \mathrm{PAO}}(\mathrm{low})$ and (high), respectively). Removal efficiencies (\%) of micropollutants during batch experiment were calculated by measuring initial and final dissolved concentration of micropollutants in the bulk solution. Removal efficiencies were calculated over 6 hours, considering the duration of phase 2 of the three systems during long-term operation.

The pseudo first-order biotransformation rate constants $k_{b i o}\left(L g_{V A S} d^{-1}\right)$ (accounting for sorption processes) were identified using the activated sludge model framework for xenobiotics (ASM-X) (Polesel et al., 2016) performed in Graph pad Prism 7.0. Statistical analyses and PHA degradation rate $\left(\mathrm{K}, \mathrm{h}^{-1}\right)$ was retrieved by using first order degradation rate in Graph pad Prism 7.0. 


\section{Results and discussion}

\subsection{Long-term operation of SBMBBR operation}

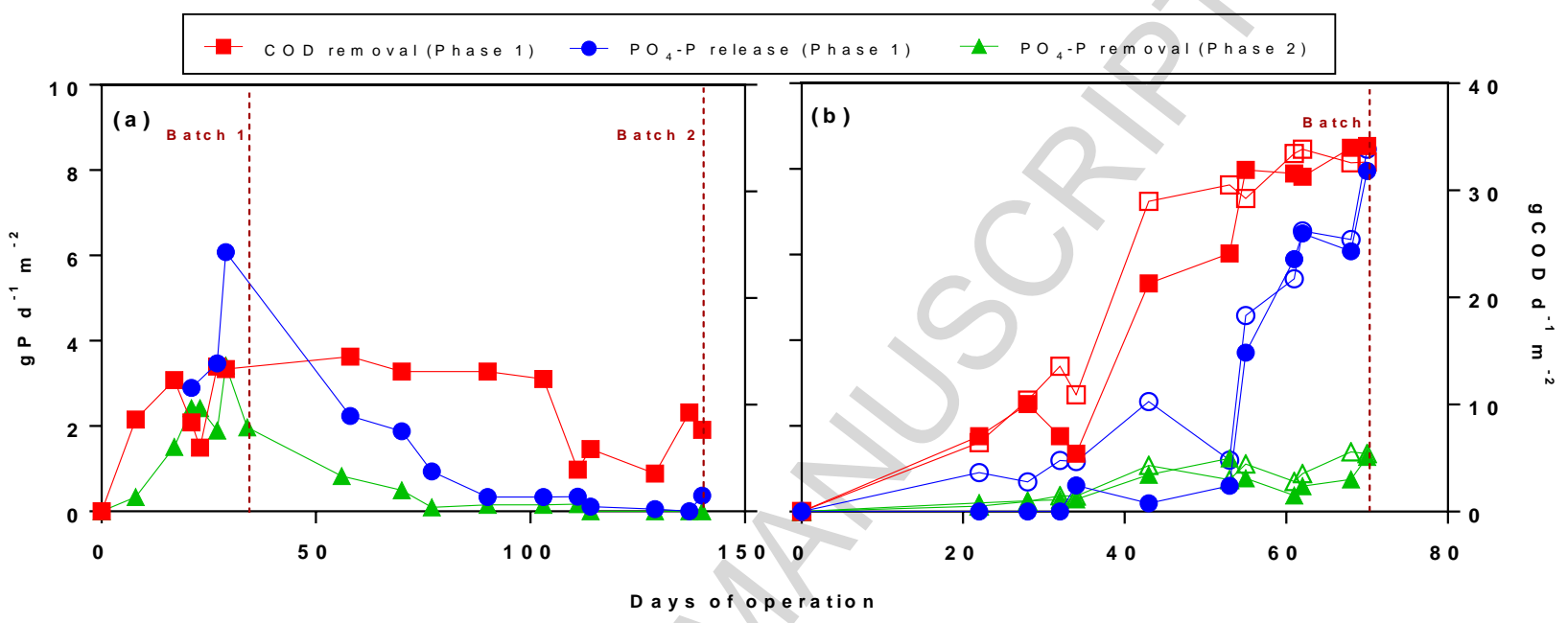

Figure 2. Data of long-term operation of the SBMBBR reactor of COD removal and phosphorus release rates under phase 1 (anaerobic phase) and phosphorus removal under phase 2 . (a) $\mathrm{R} 1_{\mathrm{PAO}}$ reactor; (b) $\mathrm{R} 2_{\mathrm{APAO}}$, full symbols and $\mathrm{R} 3_{\mathrm{DPAO}}$, empty symbols.

$\mathrm{R} 1_{\mathrm{PAO}}$ was operated for approximately 150 days. Phosphorus release and COD removal rates (expressed as carrier surface normalized, $\mathrm{g} \mathrm{d}^{-1} \mathrm{~m}^{-2}$ ) were calculated during the anaerobic phase (phase 1). For $\mathrm{R} 1_{\mathrm{PAO}}$, a gradual increase of $\mathrm{PO}_{4}-\mathrm{P}$ release and $\mathrm{COD}$ removal was observed during the first month of operation up to $6 \mathrm{~g}_{\mathrm{P}} \mathrm{d}^{-1} \mathrm{~m}^{-2}$ and $13 \mathrm{~g}_{\mathrm{COD}} \mathrm{d}^{-1} \mathrm{~m}^{-2}$, while phosphorus removal under aerobic phase reached values of $3.5 \mathrm{~g}_{\mathrm{P}} \mathrm{d}^{-1} \mathrm{~m}^{-2}$ (Fig. 2a). At the end of phase 1, the COD and $\mathrm{PO}_{4}-\mathrm{P}$ 
concentration was approximately of 150 and $50 \mathrm{mg} \mathrm{L}^{-1}$, respectively, while at the end of phase 2 the $\mathrm{PO}_{4}-\mathrm{P}$ was approximately of $5 \mathrm{mg} \mathrm{L}^{-1}$. The phosphorus release and COD uptake ratio was equal to 0.45, that was slightly lower than what reported in another SBMBBR for phosphorus and nitrogen removal (0.52, Pastorelli et al., 1999). The ratio between phosphorus uptake and release was around 0.7 .

After batch 1 (after 30 days of operation) the reactor experienced a decrease in phosphorus release and uptake (Fig. 2), but exhibiting similar COD removal, suggesting a drastic change of the microbial community composition. This could be associated to possible proliferation of GAO bacteria or PAO bacteria presenting a similar metabolism than GAO (i.e., removing VFA under anaerobic conditions and store it as PHA using glycogen as the primary energy source) (Erdal et al., 2008; Zhou et al., 2008). According to Lopez-Vazquez et al. (2009), based on a modelling investigation, the composition of VFA in this study (84\% acetate, $15 \%$ propionate), temperature of $20{ }^{\circ} \mathrm{C}$ and $\mathrm{pH}$ between 6.5 and 7 should have allowed for the coexistence of PAO and GAO.

Activity of the biofilm in $\mathrm{R} 2_{\mathrm{APAO}}$ and $\mathrm{R} 3_{\mathrm{DPAO}}$ sharply increased, reaching after 70 days of operation values of COD removal of 34 and $32 \mathrm{~g}_{\mathrm{COD}} \mathrm{d}^{-1} \mathrm{~m}^{-2}$ and phosphorus release of $8 \mathrm{~g}_{\mathrm{P}} \mathrm{d}^{-1} \mathrm{~m}^{-2}$ for R2 $\mathrm{APAO}$ and $\mathrm{R} 3_{\mathrm{DPAO}}$, respectively. At the end of phase 1 , the $\mathrm{COD}$ and $\mathrm{PO}_{4}-\mathrm{P}$ concentration in both reactors was approximately of 25 and $50 \mathrm{mg} \mathrm{L}^{-1}$, respectively, while at the end of phase 2 the $\mathrm{PO}_{4}-\mathrm{P}$ was approximately of $10 \mathrm{mg} \mathrm{L}{ }^{-1}$. Final concentration of $\mathrm{NO}_{3}-\mathrm{N}$ in $\mathrm{R} 3_{\mathrm{DPAO}}$ at the end of phase 2 was approximately of $65 \mathrm{mg} \mathrm{L}^{-1}$. Values of anaerobic COD removal were higher than what was reported in two SBMBBRs for phosphorus removal, i.e. $27.1 \mathrm{~g}_{\mathrm{P}} \mathrm{d}^{-1} \mathrm{~m}^{-2}$ (Helness and Ødegaard, 2001; Pastorelli et al., 1999) as well as compared to $\mathrm{R} 1_{\mathrm{PAO}}$. For both reactors, phosphorus removal during aerobic and anoxic phase reached values of $1.3 \mathrm{~g}_{\mathrm{P}} \mathrm{d}^{-1} \mathrm{~m}^{-2}$, which was lower than the value measured by Pastorelli et al. (1999). 


\subsection{Batch experiment 24 hours}

\subsubsection{Conventional pollutants and PHA accumulation}

Table 1 shows the calculated rates of COD removal, phosphorus release and uptake rates measured during the 24 hours batch experiments performed for the three reactors, normalized for the amount of biomass (expressed as $\left.\mathrm{g}_{\mathrm{VAS}}\right)$. $\mathrm{R} 1_{\mathrm{PAO}}$ (lowP) and (highP) indicate the results from batch 1 experiment performed for $\mathrm{R} 1_{\mathrm{PAO}}$ (section 2.3.1) that tested the influence of low and high initial phosphorus concentration in two separate batch experiment. As mentioned in 3.1 , in batch 2 for R1 $1_{\mathrm{PAO}}$, a GAO microbial population most likely was enriched in the system, and thus $\mathrm{R} 1_{\mathrm{GAO}}$ rates correspond to the results of batch 2. Profiles of measured dissolved concentration of COD, phosphorus and associated linear regressions during anaerobic phase are reported in Fig. S1 in SI.

A faster phosphorus removal rate was observed at higher initial phosphorus concentration $\left(\mathrm{R} 1_{\mathrm{PAO}}\right.$ (highP), $0.12 \mathrm{gP} \mathrm{d}^{-1} \mathrm{gVAS}^{-1}$ ) than for $\mathrm{R} 1_{\mathrm{PAO}}$ (lowP) (0.04 $\mathrm{gP} \mathrm{d}^{-1} \mathrm{gVAS}^{-1}$, Table 1). Additionally, phosphorus removal occurred only in the first 4 hours of the experiment for $\mathrm{R} 1_{\mathrm{PAO}}(\mathrm{lowP})$ and 6 hours for R1 $_{\text {PAO }}$ (highP), although phosphorus was still available in $\mathrm{R} 1_{\mathrm{PAO}}$ ( high P) (Fig. S2 in the SI). In the second batch, $\mathrm{R} 1_{\mathrm{GAO}}$ showed nor release neither uptake of phosphorus, as expected, but high COD removal under anaerobic phase (Table 1). Batch experiment for $\mathrm{R} 2_{\mathrm{APAO}}$ and $\mathrm{R} 3_{\mathrm{DPAO}}$ resulted in higher ( $\sim 3$ fold) COD removal and $\mathrm{P}$ release rate compared to $\mathrm{R} 1_{\mathrm{APAO}}$. On the other hand, phosphorus removal rates were comparable in all three reactors. Denitrification in $\mathrm{R} 3_{\mathrm{DPAO}}$ exhibited two different rates, a faster rate up to 9 hours $\left(0.1 \mathrm{gN} \mathrm{d}^{-1} \mathrm{gVAS}^{-1}\right)$ and a slower rate $\left(0.04 \mathrm{gN} \mathrm{d}^{-1} \mathrm{~g}_{\mathrm{VAS}}{ }^{-1}\right)$ for the rest of the experiment. At the end of the batch for $\mathrm{R} 3_{\mathrm{DPAO}}$, the remaining nitrate concentration was around 50 $\mathrm{mg} \mathrm{L}^{-1}$ of $\mathrm{NO}_{3}-\mathrm{N}$, maintaining anoxic condition for the duration of the experiment. 
PHA compositions in the three reactors at the end of the anaerobic phase (i.e., initial to the aerobic/anoxic phase) are presented in Table 1 . The fraction of PHAs in the biomass of $\mathrm{R} 1_{\mathrm{APAO}}$ consisted mostly of PHV. Considering the feed composition (15\% propionate, $84 \%$ acetate), this finding was in contrast to what is usually reported in literature, as the use of propionate was shown to induce mainly PHV production whereas PHB by acetate (Jiang et al., 2011). R1 $1_{\mathrm{GAO}}$ exhibited similar composition and concentration of PHA as in $\mathrm{R} 1_{\mathrm{APAO}}$, although $\mathrm{GAOs}$ have been suggested to store anaerobically higher PHA concentration than PAOs (Oehmen et al., 2007).

$\mathrm{R} 2_{\mathrm{APAO}}$ and $\mathrm{R} 3_{\mathrm{DPAO}}$ reached significantly higher PHV accumulation compared to $\mathrm{R} 1_{\mathrm{PAO}}$ (4 and 3-fold, respectively), with higher values in the aerobic reactor $\mathrm{R} 2_{\mathrm{APAO}}$. $\mathrm{PHB}$ was accumulated only in $\mathrm{R} 2_{\mathrm{APAO}}$ and $\mathrm{R} 3_{\mathrm{DPAO}}$, and not in $\mathrm{R} 1_{\mathrm{PAO}}$. Considering the similar conditions in which the three reactors were operated (e.g., VFA availability, main feed composition, temperature, $\mathrm{pH}$ ) and the obtained different PHB and PHV biomass composition, it is likely that the biomass inoculum used for the experiment ( $\mathrm{R} 1_{\text {PAO }}$ different from $\mathrm{R} 2_{\mathrm{APAO}} / \mathrm{R} 3_{\mathrm{DPAO}}$ ) might have differently influenced the enrichment of PAO and GAO community for removal of phosphorus. 
Table 1. Rates measured during batch experiments for the three reactors. VAS: volatile attached solids.

\begin{tabular}{|c|c|c|c|c|c|}
\hline & \multicolumn{2}{|c|}{ R1 PAO } & & \multirow[t]{2}{*}{ R2 } & \multirow[t]{2}{*}{ R3 $3_{\text {DPAO }}$} \\
\hline & $\begin{array}{c}\mathbf{R 1}_{\text {PAO }} \text { (lowP) } \\
\text { (Batch 1) }\end{array}$ & $\begin{array}{c}\text { R1 }_{\text {PAO }} \text { (highP) } \\
\text { (Batch 1) }\end{array}$ & $\begin{array}{l}\mathbf{R 1}_{\text {GAO }} \\
\text { (Batch 2) }\end{array}$ & & \\
\hline $\begin{array}{l}\text { COD removal rate } \\
\qquad\left(\mathrm{g} \mathrm{d}^{-1} \mathrm{gvas}^{-1}\right)\end{array}$ & & .7 & 1.7 & & 2.0 \\
\hline $\begin{array}{c}\mathrm{PO}_{4} \text {-P release rate } \\
\left(\mathrm{g} \mathrm{d}^{-1} \mathrm{gVAS}^{-1}\right)\end{array}$ & & .2 & 0 & 0.5 & 0.5 \\
\hline $\begin{array}{c}\mathrm{PO}_{4}-\mathrm{P} \text { removal } \\
\text { rate }\left(\mathrm{g} \mathrm{d}^{-1} \mathrm{gvaS}^{-1}\right)\end{array}$ & 0.04 & 0.12 & & 0.1 & 0.08 \\
\hline $\begin{array}{c}\text { Denitrification } \\
\text { rate }\left(\mathrm{g} \mathrm{d}^{-1} \mathrm{~g}_{\mathrm{VAS}}{ }^{-1}\right)\end{array}$ & 1 & I & 1 & 1 & 0.04 \\
\hline $\operatorname{VAS}\left(\mathrm{g} \mathrm{L}^{-1}\right)$ & 1.5 & & 0.5 & 1.6 & 1.8 \\
\hline $\begin{array}{l}\text { \%PHV initial } \\
\left(\mathrm{gPHV} / \mathrm{g}_{\mathrm{VAS}}\right)\end{array}$ & & .2 & 0.9 & 4.7 & 3.5 \\
\hline $\begin{array}{l}\text { \% PHB initial } \\
\text { (gPHB/g } \text { gAS })\end{array}$ & & & $\begin{array}{l}\mathrm{LOQ} \\
\end{array}$ & 1.5 & 1.7 \\
\hline
\end{tabular}




\subsubsection{Biotransformation of micropollutants in $\mathrm{R} 1_{\mathrm{PAO}}$ (aerobic conditions)}

For $\mathrm{R} 1_{\mathrm{PAO}}$, the nine targeted micropollutants were investigated in a batch experiment at low $\left(8 \mathrm{mg} \mathrm{L}^{-1}\right)$ and high $\left(30 \mathrm{mg} \mathrm{L}^{-1}\right)$ initial phosphorus concentration (blue symbols and line in Fig. 3). This was done to investigate if there was a notable enhancement or inhibition of the primary substrate (phosphorus) on the cometabolic activity of the PAO community. With exception of phosphorus concentration, feed composition, $\mathrm{pH}, \mathrm{T}$ and biomass concentration were kept equal in the two reactors ( $\mathrm{R}_{1 \mathrm{PAO}}($ lowP) and $\mathrm{R}_{1 \mathrm{PAO}}($ highP)).

Biotransformation kinetics of most of the investigated chemicals could be described with first-order equation $\left(\mathrm{R}^{2}>0.9\right.$, Table $\mathrm{S} 2$ in $\left.\mathrm{SI}\right)$, thereby allowing for the estimation of pseudo-first order biotransformation rate constants $\mathrm{k}_{\mathrm{Bio}}\left(\mathrm{L} \mathrm{g}_{\mathrm{VAS}}{ }^{-1} \mathrm{~d}^{-1}\right)$ (Table 2$)$.

We observed a substantial difference (20\% up to $60 \%$ ) in removal between $\mathrm{R} 1_{\mathrm{PAO}}(\mathrm{lowP})$ and $\mathrm{R} 1_{\mathrm{PAO}}$ (highP) for benzotriazole, 5-methyl-1H-Benzotriazole, carbamazepine, ketoprofen and diclofenac

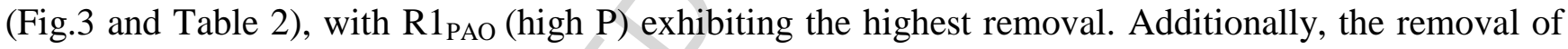
those compounds occurred only in the first 4 hours of the experiment for $\mathrm{R} 1_{\mathrm{PAO}}(\mathrm{lowP})$ and 6 hours for $\mathrm{R} 1_{\mathrm{PAO}}$ (highP), when the phosphorus was still available in the two reactors (Fig. S2 in the SI).

This suggests a first indication of cometabolic activity of PAO towards the removal of those compounds that ceased when the primary substrate (phosphorus) and/or the internal stored PHA was no longer available. When comparing $\mathrm{R} 1_{\mathrm{PAO}}$ (lowP) and $\mathrm{R}_{1 \mathrm{PAO}}$ (highP) in the first 4 and 6 hours respectively, a significant $(\mathrm{p}<0.05)$ faster removal was observed at initial lower phosphorus concentration for carbamazepine, ketoprofen and diclofenac. As no evidence exists on the removal of those targeted micropollutants under biological enhanced phosphorus removal, biodegradation kinetics and efficiencies are compared to previous studies performed on MBBR and on activated sludge. 
Benzotriazole and 5-H-methyl-benzotriazole removal was previously investigated in a two-stage aerobic MBBR and activated sludge (Mazioti et al., 2015), showing $\mathrm{k}_{\mathrm{Bio}}$ (normalized on suspended solids) 10 times lower than the ones reported in this study. The predicted removal of benzotriazole ranged within $40-70 \%$ in the high and low loaded MBBR, respectively, which is comparable to this study (during the first 6 hours of the experiment). On the other hand, significant higher removal of 5methy-1H-benzotriazole (29-76\%) was observed in this study compared to Mazioti et al. (2015) $(<20 \%)$, suggesting the efficiency of a PAO enriched community towards the removal of this compound. Carbamazepine is known to be a recalcitrant compound under most of the conditions in biological treatment (Falås et al., 2016). In this study, we observed a removal of $47-66 \%$ in the first 4 and 6 hours under aerobic phosphorus removal in $\mathrm{R} 1_{\mathrm{PAO}}\left(\right.$ lowP) and $\mathrm{R} 1_{\mathrm{PAO}}$ (highP), respectively, suggesting an efficient cometabolic activity of PAO enriched community. Although this is a promising result for carbamazepine, further investigation was carried out in the following experiment $\left(\mathrm{R} 22_{\mathrm{APAO}}\right)$ to support this finding (section 3.2.2). Similarly, diclofenac presented a significantly faster removal $\mathrm{k}_{\mathrm{Bio}}$ (in the first 4 and 6 hours in both reactors) compared to other studies with nitrifying MBBR (Torresi et al., 2016) and other biological process configurations (Vieno and Sillanpää, 2014), indicating the need for further investigation.

No major removal of clofibric acid (the main metabolite of clofibrate) was observed, while Falås et al. (2012) showed a removal in aerobic MBBR, although 3-8 times lower than what was observed in activated sludge (Joss et al., 2006). Bezafibrate was equally removed ( 10\%, Table 2 ) in both $\mathrm{R} 1_{\mathrm{PAO}}$ (lowP) and $\mathrm{R} 1_{\mathrm{PAO}}$ (highP), with $\mathrm{k}_{\mathrm{Bio}}$ in the range of the one presented in Falås et al. (2016). This supports the hypothesis that bezafibrate is generally removed in mainly aerobic environment, also during phosphorus removal. Ibuprofen was removed faster in $\mathrm{R} 1_{\mathrm{PAO}}\left(\right.$ low $\mathrm{P}$ ) compared to $\mathrm{R} 1_{\mathrm{PAO}}(\mathrm{highP})$, however with $\mathrm{k}_{\mathrm{Bio}}$ similar or lower than what previously was measured in aerobic MBBR (Falås et al., 
2012; Torresi et al., 2016) and in general lower then what was observed for nitrifying-aerobic activated sludge (Joss et al., 2006; Suarez et al., 2010) This suggests that PAO activity for ibuprofen was lower than other heterotrophic and nitrifying bacteria. $\mathrm{K}_{\mathrm{Bio}}$ for gemfibrozil was double at initial higher phosphorus concentration and in general higher than what was measured in a nitrifying MBBR (Falås et al., 2012).

In the batch experiment 2 , in $\mathrm{R} 1_{\mathrm{GAO}}$, most of the micropollutants were not removed (symbols and continuous red lines in Fig. 3) and only a removal of approximately $20 \%$ was measured for benzotriazole, clofibric acid, gemfibrozil and ibuprofen. Only ibuprofen presented $\mathrm{k}_{\text {Bio }}$ comparable to batch 1 , however with kinetics significantly lower than what usually measured for activated sludge (Joss et al., 2006) or nitrifying MBBR (Torresi et al., 2016). Overall, results from batch 2 suggest that a community mostly populated by GAO, although able to store PHA at concentration similar to $\mathrm{R} 1_{\mathrm{APAO}}$ (Table 1), may not exhibit a significant biotransformation activity for the targeted micropollutants. 


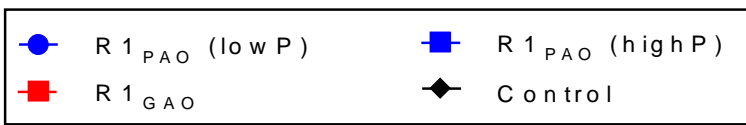
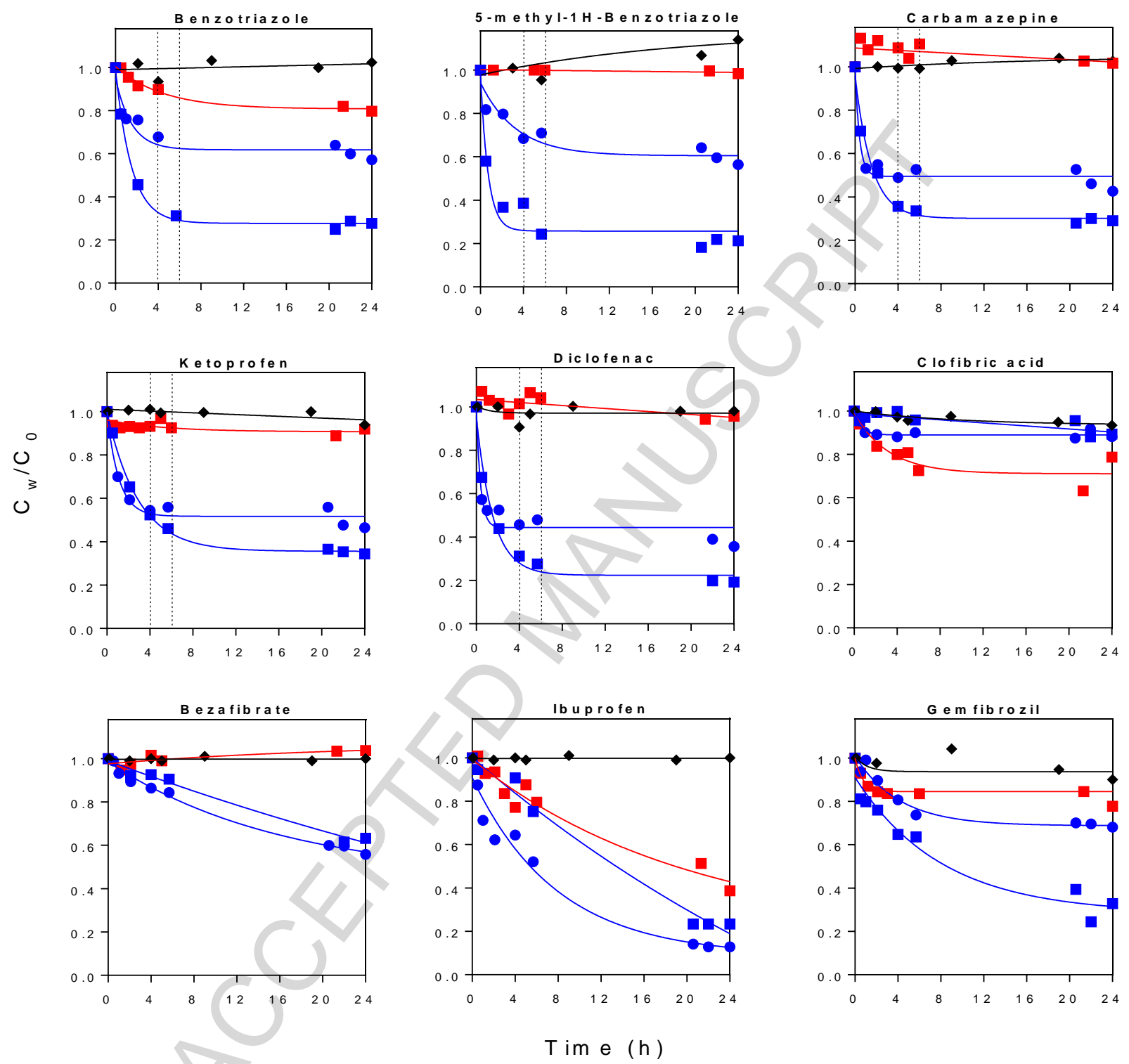

Figure 3. Measured and simulated concentration profiles of micropollutants in reactor $\mathrm{R} 1_{\mathrm{PAO}}($ low $\mathrm{P}$ ), $\mathrm{R} 1_{\mathrm{PAO}}\left(\right.$ highP) in blue and $\mathrm{R} 1_{\mathrm{GAO}}$ in red. Dotted lines at 4 and $6 \mathrm{~h}$ indicate the time when phosphorus is no longer available for $\mathrm{R} 1_{\mathrm{PAO}}$ (lowP) and (highP), respectively. Black symbols and lines show results of the control experiment (abiotic removal). 
Table 2. Biodegradation rate constants and removal efficiency calculated for the first 6 hours of experiment for $\mathrm{R} 1_{\mathrm{PAO}}$ during batch $1\left(\mathrm{R} 1_{\mathrm{PAO}}\left(\right.\right.$ lowP) and (highP)) and batch $2\left(\mathrm{R}_{1 \mathrm{GAO}}\right)$.

\begin{tabular}{|c|c|c|c|c|c|c|}
\hline & \multicolumn{2}{|c|}{ R1 $_{\text {PAO }}($ low P) } & \multicolumn{2}{|c|}{ R1 $_{\text {PAO }}$ (high P) } & \multicolumn{2}{|c|}{$\mathbf{R} \mathbf{1}_{\mathrm{GAO}}$} \\
\hline & $\mathrm{k}_{\text {Bio }}$ & Removal & $\mathrm{k}_{\text {Bio }}$ & Removal & $\mathrm{k}_{\text {Bio }}$ & Removal \\
\hline & $\left(\operatorname{Lg}_{\mathrm{VAS}^{-1}} \mathrm{~d}^{-1}\right)$ & $(\%)$ & $\left(\operatorname{Lg}_{\left.\mathrm{VAS}^{-1} \mathrm{~d}^{-1}\right)}\right.$ & $(\%)$ & $\left(\mathrm{Lg}_{\left.\mathrm{VAS}^{-1} \mathrm{~d}^{-1}\right)}\right.$ & $(\%)$ \\
\hline Benzotriazole & $12.5 \pm 3.9$ & 32 & $12.4 \pm 0.7$ & 69 & $.5 \pm 0.9$ & 18 \\
\hline 5-methyl-1H- & $5.6 \pm 1.6$ & 29 & $25.9 \pm 6.7$ & & n.d & I \\
\hline Carbamazepine & $45.4 \pm 16.1$ & 47 & $12.1 \pm 1.7$ & 66 & n.d & 7 \\
\hline Ketoprofen & $49.6 \pm 11.2$ & 44 & $6.4 \pm 0.2$ & 54 & n.d & $/$ \\
\hline Diclofenac & $47.2 \pm 11.6$ & 52 & $11.9 \pm 2.0$ & 72 & n.d & I \\
\hline Clofibric acid & n.d & I & n.d & / & $5.0 \pm 1.8$ & 27 \\
\hline Bezafibrate & $1.1 \pm 0.3$ & 16 & $0.3 \pm 0.2$ & 10 & n.d & / \\
\hline Ibuprofen & $2.4 \pm 0.6$ & 48 & $0.4 \pm 0.4$ & 25 & $0.9 \pm 0.6$ & 21 \\
\hline Gemfibrozil & $4.6 \pm 0.8$ & & $2.3 \pm 0.6$ & 36 & $25.9 \pm 15.3$ & 16 \\
\hline
\end{tabular}

\subsubsection{Abiotic removal of micropollutants}

As described previously (Torresi et al., 2017b), sorption of spiked micropollutants was considered significant when a relative concentration drop of measured initial and final concentration was higher than $10 \%$, thus accounting for analytical uncertainty. Profiles of aqueous concentration of the sorptive micropollutants measured during batch experiments for $\mathrm{R} 2_{\mathrm{APAO}}$ and $\mathrm{R} 3_{\mathrm{DAO}}$ are shown in Figure in $\mathrm{S} 3$.

Only diclofenac, gemfibrozil and ketoprofen presented significant removal (\%) due to sorption to biomass in 24 hours of experiment. As observed in Torresi et al. (2017b), equilibrium in thick biofilm (> $200 \mu \mathrm{m}$ ) may not be reached within the duration of the batch experiment (usually performed within 
4 hours, and here in 24 hours). Therefore calculation of the distribution coefficient $\mathrm{K}_{\mathrm{d} \text {,eq }}$ was based on the approximation of the asymptotic equilibrium concentration, as suggested in Torresi et al. (2017b). Value of $\mathrm{K}_{\mathrm{d} \text {,eq }}$ were 1.3-1.6 for diclofenac, 0.9-0.7 for ketoprofen and 0.3-0.3 $\mathrm{L} \mathrm{g}^{-1}$ for gemfibrozil for $\mathrm{R} 2_{\mathrm{APAO}}$ and $\mathrm{R} 3_{\mathrm{DPAO}}$, respectively. Interestingly, no significant difference was observed in the two $\mathrm{K}_{\mathrm{d} \text {,eq }}$, estimated for aerobic and anoxic carriers. In our previous work, sorption of diclofenac to biofilm (Zcarriers) were found insignificant, as well as in other studies (reviewed in Vieno and Sillanpää (2014)). This could be due to the ionization state of diclofenac that at $\mathrm{pH}$ typical of wastewater treatment plant of 7.5 (similarly to this study) has a negatively ionized carboxylic acid moiety, which repels the negatively charged biomass. Thus, the significant sorption coefficient measured in both $\mathrm{R} 2_{\mathrm{APAO}}$ and R3 $3_{\text {DPAO }}$ should be further investigated. Mazioti et al. (2015) showed that sorption was of minor importance for both benzotriazole and 5-methyl-1H-Benzotriazole in an aerobic MBBR, similarly to this study. Values of sorption for ketoprofen are higher than $\mathrm{K}_{\mathrm{d} \text {,eq }}$ measured in primary activated sludge and MBR (0.22 $\mathrm{L} \mathrm{g}^{-1}$, Radjenović et al., 2009) while for gemfibrozil similar sorption coefficient was observed $\left(0.3 \mathrm{~L} \mathrm{~g}^{-1}\right)$.

No major removal due to other abiotic processes (e.g., sorption to glass wall, plastic, volatilization and hydrolysis) was observed for the targeted micropollutants (black symbols in Fig. 3 and. Fig. 4).

\subsubsection{Biotransformation of micropollutants in $R 2_{\mathrm{APAO}}$ (aerobic conditions) and $\mathrm{R} 3_{\mathrm{DPAO}}$ (anoxic conditions)}

Reactors $\mathrm{R} 2_{\mathrm{APAO}}$ and $\mathrm{R} 3_{\mathrm{DPAO}}$ were operated to compare the performance of PAO community under aerobic and anoxic conditions, respectively. Generally, the batch experiment for R $2_{\mathrm{APAO}}$ was performed under similar conditions of $\mathrm{R} 1_{\mathrm{PAO}}$ (highP), although the two reactors were inoculated with different 
biomass, taken from two existing pilot plants. When comparing $\mathrm{R} 2_{\mathrm{APAO}}$ and $\mathrm{R} 1_{\mathrm{PAO}}$ under aerobic conditions, the five compounds that previously presented a slowdown of degradation when phosphorus was over (Fig. 3) were still degraded in $\mathrm{R} 2_{\mathrm{APAO}}$ for the rest of the experiment but with lower $\mathrm{k}_{\mathrm{Bio}}$. Despite this, $\mathrm{k}_{\mathrm{Bio}}$ for benzotriazole and 5-methyl-1H-Benzotriazole were in the range of the kinetics measured in a two stage aerobic MBBR treating full strength wastewater $(0.58-2.46$ for benzotriazoles and 0.7 for 5-methyl-1H-Benzotriazole, Mazioti et al., 2015). The removal of carbamazepine under aerobic conditions was poor, not supporting what previously found for $\mathrm{R} 1_{\mathrm{PAO}}$. However, the difference in biomass composition may have influenced the measured activity of the two aerobic PAO communities. Due to analytical uncertainties, ibuprofen could not be measure in this experiment. Interesting, diclofenac and ketoprofen presented a lag-phase prior degradation until 4 hours of batch experiment for $\mathrm{R} 2 \mathrm{APAO}$ (Fig. 4). Diclofenac exhibited $\mathrm{k}_{\mathrm{Bio}}$ in the range of what observed by using MBBR carriers from a full-scale plant (Falås et al., 2012) and a lab-scale three-stage MBBR configuration (Escolà Casas et al., 2015), but lower of what observed in a polishing MBBR pilot fed with intermitting feeding ( $\mathrm{k}_{\mathrm{Bio}}$ of $5.5 \mathrm{~L} \mathrm{~g}^{-1} \mathrm{~d}^{-1}$ ) (Tang et al., 2017). Conversely to what observed in $\mathrm{R} 1_{\mathrm{PAO}}$, clofibric acid was biodegraded to a certain extent, with $\mathrm{k}_{\mathrm{Bio}}$ significantly higher to what was observed in a previous aerobic MBBR (Falås et al., 2012). Overall, obtained removal efficiency (\%) calculated over the 6 hours of batch experiment for $\mathrm{R} 2_{\mathrm{APAO}}$ was comparable to the efficiency $\mathrm{R} 1_{\mathrm{PAO}}$ (with exception of bezafibrate), confirming the potential of the enriched PAO community in the biodegradation of these compounds.

When comparing aerobic to anoxic conditions ( $\mathrm{R} 2_{\mathrm{APAO}}$ and $\mathrm{R} 3_{\mathrm{DPAO}}$ ), only benzotriazole and carbamazepine were removed to similar extent, while most of the compounds were not removed or presented lower removal under anoxic conditions. Removal of carbamazepine has previously been observed in anoxic post-denitrifying MBBRs (Torresi et al., 2017a), confirming its removal under those 
conditions. Conversely, diclofenac under anoxic condition was confirmed to be non-degradable as previously observed in pre- and post-denitrifying MBBR (Polesel et al., 2017; Torresi et al., 2017a).

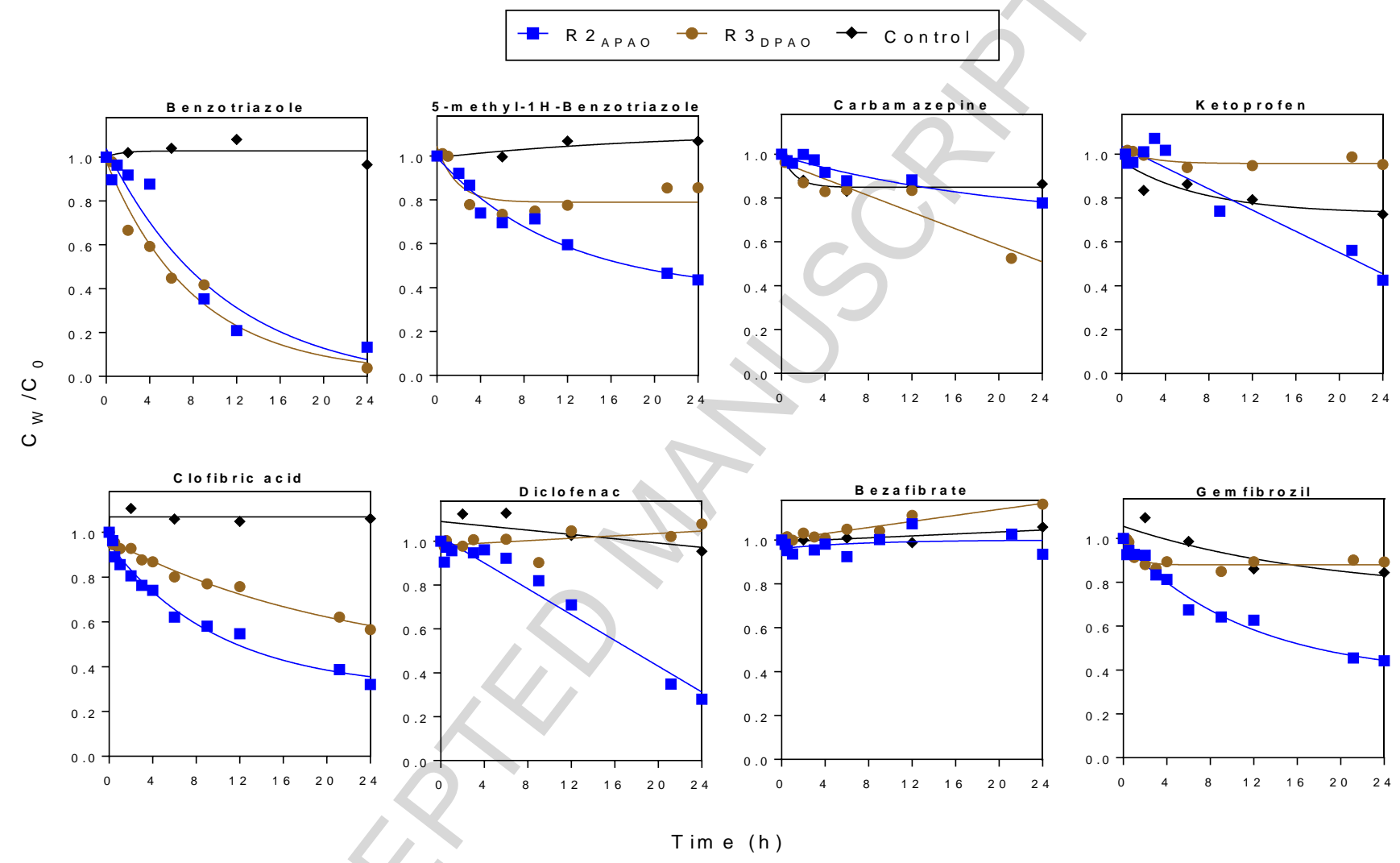

Figure 4. Measured and simulated concentration profiles of micropollutants in reactor $\mathrm{R} 2_{\mathrm{APAO}}$ and $\mathrm{R} 3_{\mathrm{DPAO}}$. 
Table 2. Biodegradation rates and removal efficiency calculated for the first 6 hours of the batch experiment for $\mathrm{R} 2_{\mathrm{APAO}}\left(\right.$ aerobic $\mathrm{PAO}$ ) and $\mathrm{R} 3_{\mathrm{DPAO}}$ (denitrifying PAO). Asterisks * indicate compounds that show significant sorption removal ( $\mathrm{K}_{\mathrm{d}, \mathrm{eq}}$ included in the estimation of the biotransformation kinetics).

\begin{tabular}{c|c|c|c|c}
\hline & \multicolumn{2}{|c|}{$\mathbf{R 2}_{\mathrm{APAO}}$} & \multicolumn{2}{c}{$\mathbf{R 3}_{\text {DPAO }}$} \\
\hline & $\mathrm{k}_{\mathrm{Bio}}$ & Removal & $\mathrm{k}_{\mathrm{Bio}}$ & Removal \\
& $\left(\mathrm{L} \mathrm{g}_{\mathrm{VAS}}{ }^{-1} \mathrm{~d}^{-1}\right)$ & $(\%)$ & $\left(\mathrm{L} \mathrm{g}_{\mathrm{VAS}}^{-1} \mathrm{~d}^{-1}\right)$ & $(\%)$ \\
\hline Benzotriazole & $1.5 \pm 0.3$ & 42 & $1.6 \pm 0.2$ & 55 \\
\hline 5-methyl-1H-Benzotriazole & $0.5 \pm 0.1$ & 29 & $0.1 \pm 0.1$ & 25 \\
\hline Carbamazepine & $0.2 \pm 0.0$ & 12 & $0.3 \pm 0.1$ & 16 \\
\hline Ketoprofen* & $1.2 \pm 0.1$ & 14 & $\mathrm{n} . \mathrm{d}$ & 6 \\
\hline Diclofenac* & $1.8 \pm 0.1$ & 8 & $\mathrm{n} . \mathrm{d}$ & 0 \\
\hline Clofibric acid & $1.5 \pm 0.3$ & 38 & $0.6 \pm 0.2$ & 20 \\
\hline Bezafibrate & $\mathrm{n} . \mathrm{d}$ & $/$ & $\mathrm{n} . \mathrm{d}$ & $/$ \\
\hline Gemfibrozil* & $0.8 \pm 0.0$ & 33 & $\mathrm{n} . \mathrm{d}$ & 0 \\
\hline
\end{tabular}

\subsection{PHA utilization and micropollutants biodegradation in $R 2_{\mathrm{APAO}}$ and $\mathrm{R} 3_{\mathrm{DPAO}}$}

PHB and PHV concentrations in the biomass were measured over 24 hours of batch experiment, performed for the three reactors. Unfortunately, for $\mathrm{R} 1_{\mathrm{PAO}}$, only the initial concentration of PHA was quantifiable, while the subsequent 10 samples were under the level of quantification (LOQ). Therefore, for $\mathrm{R} 1_{\mathrm{PAO}}$, the removal observed in Fig. 3 could indicate a possible cometabolic activity of the PAO community with the uptake of phosphorus, with the degradation of stored PHA, or a combination of the 
two mechanisms. Therefore, only concentration profiles measured during the batch experiment for $\mathrm{R} 2_{\mathrm{APAO}}$ and $\mathrm{R} 3_{\mathrm{DPAO}}$ are presented (Fig. 5).

PHA degradation rates in the biofilm reactors were previously observed to follow first order degradation rates (Krasnits et al., 2013). In $\mathrm{R} 2_{\mathrm{APAO}}$, both $\mathrm{PHB}$ and $\mathrm{PHV}$ exhibited a degradation rate $\mathrm{K}$ of $0.35 \pm 0.16 \mathrm{~h}^{-1}$. For $\mathrm{R} 3_{\mathrm{DPAO}}$, a faster degradation rate $\mathrm{K}$ for $\mathrm{PHB}\left(\mathrm{K}=0.33 \pm 0.10 \mathrm{~h}^{-1}\right)$ than for PHV $\left(\mathrm{K}=0.10 \pm 0.05 \mathrm{~h}^{-1}\right)$ was observed. Values of degradation rates of PHA are similar to those estimated for denitrifying biofilm reactors fed with synthetic wastewater (Krasnits et al., 2013) and in activated sludge (Beun et al., 2000). However, higher PHA degradation rates were measured in the same study when using real wastewater (Krasnits et al., 2013). Lower PHA degradation rates in biofilm compared to suspended sludge were associated with diffusion limitation exhibited in biofilms (Krasnits et al., 2013).

For $\mathrm{R} 2 \mathrm{APAO}$ under aerobic conditions, the fraction of $\mathrm{PHB}$ was removed in the first 4 hours of experiment (Fig. 5), simultaneously to the removal of phosphorus, while the removal of PHV continued during the 24 hours. Noticeable, a lag-phase of 4 hours before biodegradation was observed for the compounds diclofenac and ketoprofen (Fig. 4), which may be related to a possible inhibition in their biodegradations by PHB and phosphorus removal. The lag-phase terminated when PHB was fully consumed. Due to the absence of PHB in reactor $\mathrm{R} 1_{\mathrm{PAO}}$, the inhibition might not have been visible in the aerobic batch in $\mathrm{R} 1_{\mathrm{PAO}}$. Under anoxic condition, in $\mathrm{R} 3_{\mathrm{DPAO}}$, phosphorus and nitrate removal occurred simultaneously to the micropollutant biodegradation. As shown in Fig. 5, PHB was mainly degraded during time when phosphorus removal occurred (in this case approximately 5 hours), during simultaneous removal of PHV. Additionally, in R3 $3_{\mathrm{DPAO}}$, PHV degradation occurs over the 24 hours of the experiment, due to the reducing energy needed for the denitrification. As no additional carbon source was present in the feed during phase 2 of the batch experiment, it is likely that PHV was related 
with the biodegradation of micropollutants. As no evidences are present regarding PHA degradation and micropollutant removal, further research should be carried out to assess the specific contribution of the different PHA fractions on biodegradation of trace compounds.

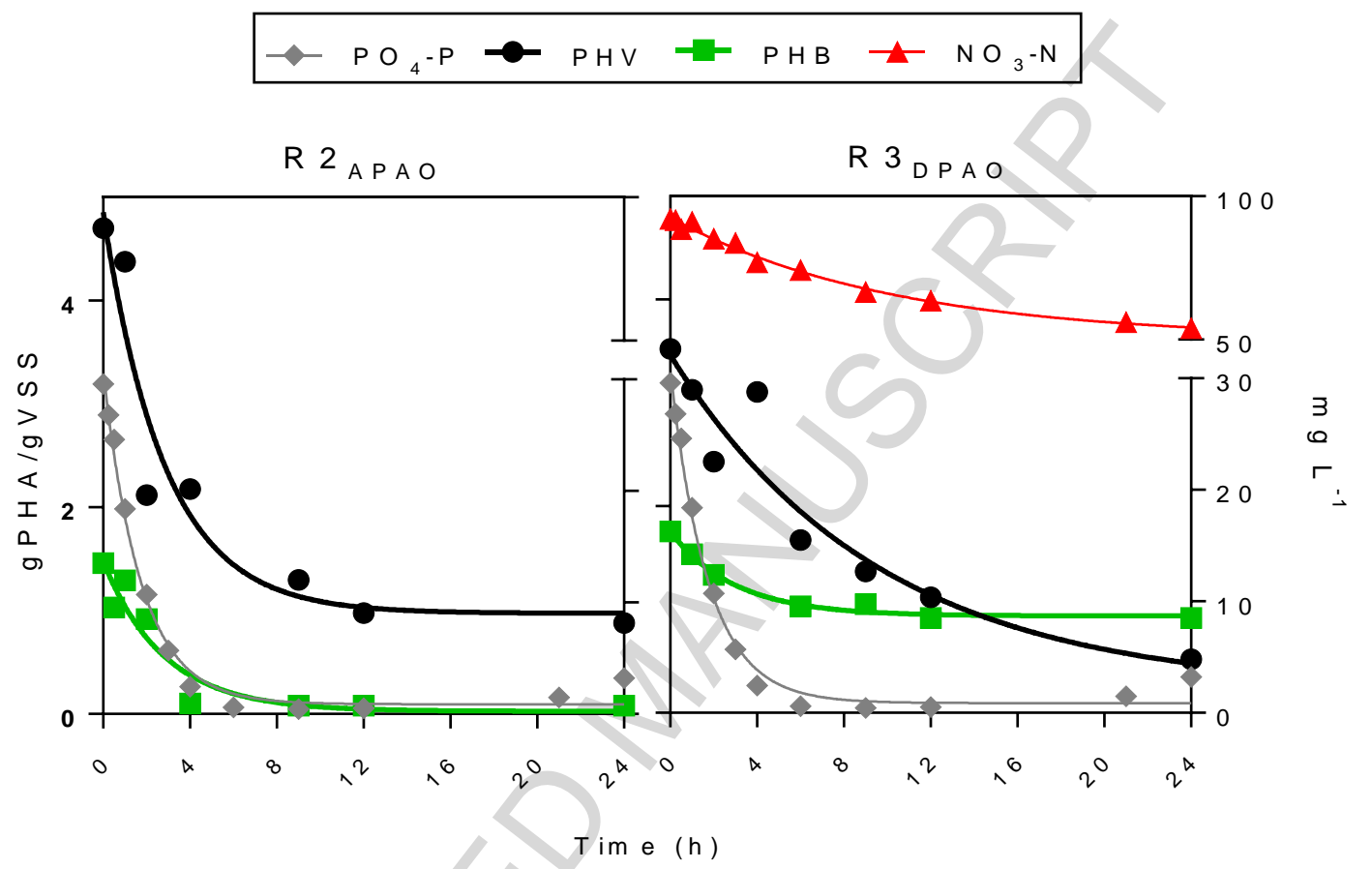

Figure 5. Measured and simulated concentration profiles of phosphorus, PHB, PHV and nitrate in reactor $\mathrm{R} 2_{\mathrm{APAO}}$ and $\mathrm{R} 3_{\mathrm{DPAO}}$

\subsection{Application and future considerations}

One of the major limitations of using biological treatment as polishing technology in WWTPs is the difficulty in maintaining sufficient biofilm growth and activity at low available concentration of carbon, nitrogen and other nutrients in the effluent wastewater. Intermitted feeding of aerobic MBBR between pre-clarified wastewater (by-passed at the last stage of WWTP and recirculated to primary 
settler) and effluent wastewater has been shown to be a valid solution to maintain substantial biomass concentration and activity at a tertiary biological treatment (Tang et al., 2017). This study was performed to investigate another possibility for operation and feed strategy of polishing MBBR: an intermitting feeding of the biofilm with pre-clarified wastewater under anaerobic conditions, which in return will favour the enrichment of PAO community and PHA storage. The results suggest that the PHA stored in under anaerobic conditions can subsequently be used in the effluent wastewater stream to maintain biofilm growth, to treat the remaining phosphorus and nitrogen (if anoxic conditions are applied) and in addition also micropollutants. Such operational strategy is currently under investigation in a polishing pilot-scale MBBR (funded by Innovationsfonden Denmark and based on the Swedish patent 1650321-1.a by Veolia Water Technologies), consisting of two wastewater lines (Fig. 6): a side stream (treating pre-clarified wastewater) under anaerobic conditions, where PHA are stored, and a second line (treating effluent wastewater) under consecutive anoxic and aerobic conditions. Intermittingly, the flows between the two lines are shifted and the reactor previously exposed to anaerobic conditions (reactor C in Fig.6) is set on the polishing line (in the position of A reactor) to treat effluent wastewater, as previously described in Tang et al. 2017. Notably, the new concept relies on the side stream of pre-clarified wastewater being returned to the main wastewater treatment line (i.e., after pre-clarification), not affecting the quality of the effluent wastewater.

In addition to the testing of the new operational concept for tertiary treatment of micropollutants, the pilot will serve as validation of the results of this study that relied on synthetic wastewater and was found highly dependent on the inoculum media. 


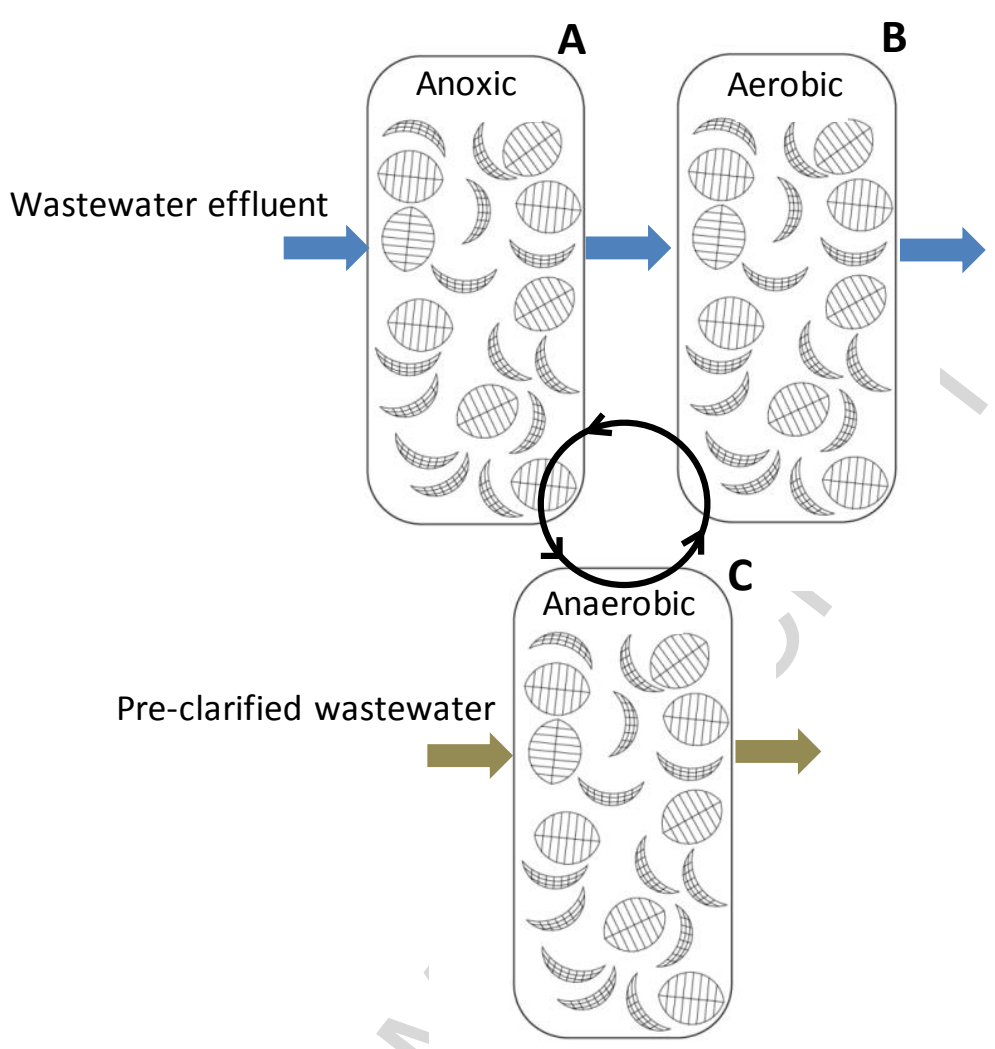

Figure 6. Schematic view of the polishing pilot that test the intermitting feeding concept developed by Veolia Water Technologies (Swedish patent 1650321-1.a) as additional polishing technology to treat effluent wastewater. 


\section{Conclusion}

Three lab-scale MBBRs were operated under different redox conditions to investigate the potential of removing nine targeted micropollutants, by monitoring the biodegradation of stored PHA. Based on targeted batch experiments, we could draw the following conclusions:

- Although the three lab-scale MBBR were operated with similar conditions (e.g., feed composition, $\mathrm{pH}$, temperature), the different inoculum biofilm strongly influenced the activity and the PHA composition of the microbial community.

- Under aerobic conditions ( $\left.\mathrm{R} 1_{\mathrm{PAO}}\right)$, higher removal $(\%)$ of most of the micropollutants was observed at higher initial $\mathrm{PO}_{4}-\mathrm{P}$ concentration $\left(30 \mathrm{mg} \mathrm{L}^{-1}\right)$ compared to lower concentration (8 mg $\mathrm{L}^{-1}$ ), suggesting a cometabolic activity of the PAO enriched community. Removal of benzotriazole, 5-methyl-1H-benzotriazole, carbamazepine, ketoprofen and diclofenac occurred only in the first 6 hours of experiment, simultaneously to phosphorus removal and terminated when phosphorus was no longer available.

- When the microbial community in $\mathrm{R} 1_{\mathrm{APAO}}$ shifted to mainly $\mathrm{GAO}$ enriched community $\left(\mathrm{R} 1_{\mathrm{GAO}}\right)$, the removal of most of micropollutants was insignificant, with exception of clofibric acid and ibuprofen.

- Under aerobic conditions, $\mathrm{R} 2_{\mathrm{APAO}}$ exhibited similar removal efficiency to $\mathrm{R} 1_{\mathrm{APAO}}$ of most of the micropollutants (with exception of bezafibrate), although with lower $\mathrm{k}_{\mathrm{Bio}}$.

- The removal efficiency of most of targeted micropollutants was significantly reduced (from 20 to $80 \%$ reduction) under anoxic conditions $\left(\mathrm{R} 3_{\mathrm{DPAO}}\right)$.

- Results from measured PHA concentration showed that phosphorus removal likely was driven by simultaneous degradation of PHB and PHV fractions during the first 4-6 hours of batch 
experiment. On the other hand, biodegradation of PHV occurred over the whole duration of the experiment, simultaneously to the removal of the targeted micropollutants and nitrate (in $\left.\mathrm{R} 3_{\mathrm{DPAO}}\right)$.

\section{Supplementary information}

E-supplementary data of this work can be found in online version of the paper

\section{ACKNOWLEDGMENTS}

This research was supported by Innovationsfonden Denmark under grant agreeement n. 5190-000318. 


\section{References}

Benner, J., Helbling, D.E., Kohler, H.-P.E., Wittebol, J., Kaiser, E., Prasse, C., Ternes, T. a, Albers, C.N., Aamand, J., Horemans, B., Springael, D., Walravens, E., Boon, N., 2013. Is biological treatment a viable alternative for micropollutant removal in drinking water treatment processes? Water Res. 47, 5955-76.

Beun, J.J., Verhoef, E.V., Van Loosdrecht, M.C.M., Heijnen, J.J., 2000. Stoichiometry and kinetics of poly-b-hydroxybutyrate metabolism under denitrifying conditions in activated sludge cultures. Biotechnology and Bioengineering 68 (5), 496-507

Coats, E.R., Mockos, A., Loge, F.J., 2011. Post-anoxic denitrification driven by PHA and glycogen within enhanced biological phosphorus removal. Bioresour. Technol. 102, 1019-1027.

Daughton, C.G., Ternes, T.A., 1999. Pharmaceuticals and personal care products in the environment: agents of subtle change? Environ. Health Perspect. 907-38.

Dias, J.M.L., Lemos, P.C., Serafim, L.S., Oliveira, C., Eiroa, M., Albuquerque, M.G.E., Ramos, A.M., Oliveira, R., Reis, M. a M., 2006. Recent advances in polyhydroxyalkanoate production by mixed aerobic cultures: from the substrate to the final product. Macromol. Biosci. 6, 885-906.

Escolà Casas, M.E., Chhetri, R.K., Ooi, G., Hansen, K.M.S., Litty, K., Christensson, M., Kragelund, C., Andersen, H.R., Bester, K., 2015. Biodegradation of pharmaceuticals in hospital wastewater by staged Moving Bed Biofilm Reactors (MBBR). Water Res. 83, 293-302.

Erdal, U. G., Erdal, Z. K., Daigger, G. T., \& Randall, C. W. (2008). Is it PAO-GAO competition or metabolic shift in EBPR system ? Evidence from an experimental study, 1329-1334.

Falås, P., Baillon-Dhumez, a, Andersen, H.R., Ledin, a, la Cour Jansen, J., 2012. Suspended biofilm carrier and activated sludge removal of acidic pharmaceuticals. Water Res. 46, 1167-75. 
Falås, P., Wick, A., Castronovo, S., Habermacher, J., Ternes, T.A., Joss, A., 2016. Tracing the limits of organic micropollutant removal in biological wastewater treatment. Water Res. 95, 240-249.

Garric J, Vollat B, Nguyen DK, et al. (1996) Ecotoxicological and chemical characterization of municipal wastewater treatment plant effluents. Water Science and Technology 33: 83-91

Hapeshi, E., Lambrianides, a, Koutsoftas, P., Kastanos, E., Michael, C., Fatta-Kassinos, D., 2013. Investigating the fate of iodinated X-ray contrast media iohexol and diatrizoate during microbial degradation in an MBBR system treating urban wastewater. Environ. Sci. Pollut. Res. Int. 20, 3592-606.

Helness, H., Ødegaard, H., 2001. Biological phosphorus and nitrogen removal in a sequencing batch moving bed biofilm reactor. Water Sci. Technol. 43, 233-40.

Hoeger, B., Köllner, B., Dietrich, D.R., Hitzfeld, B., 2005. Water-borne diclofenac affects kidney and gill integrity and selected immune parameters in brown trout (Salmo trutta f.fario). Aquat. Toxicol. 75, 53-64.

Jiang, Y., Hebly, M., Kleerebezem, R., Muyzer, G., van Loosdrecht, M.C.M., 2011. Metabolic modeling of mixed substrate uptake for polyhydroxyalkanoate (PHA) production. Water Res. 45, $1309-1321$.

Joss, A., Zabczynski, S., Göbel, A., Hoffmann, B., Löffler, D., McArdell, C.S., Ternes, T. a., Thomsen, A., Siegrist, H., 2006. Biological degradation of pharmaceuticals in municipal wastewater treatment: Proposing a classification scheme. Water Res. 40, 1686-1696.

Knopp, G., Prasse, C., Ternes, T., Cornel, P., 2016. Elimination of micropollutants and transformation products from a wastewater treatment plant effluent through pilot scale ozonation followed by various activated carbon and biological filters. Water Res.

Krasnits, E., Beliavsky, M., Tarre, S., Green, M., 2013. PHA based denitrification: Municipal 
wastewater vs. acetate. Bioresour. Technol. 132, 28-37.

Lopez-Vazquez, C.M., Oehmen, A., Hooijmans, C.M., Brdjanovic, D., Gijzen, H.J., Yuan, Z., van Loosdrecht, M.C.M., 2009. Modeling the PAO-GAO competition: Effects of carbon source, pH and temperature. Water Res. 43, 450-462.

Margot, J.; Rossi, L.; Barry, D. A.; Holliger, C. A review of the fate of micropollutants in wastewater treatment plants. Wiley Interdiscip. Rev.: Water 2015, 2 (5), 457-487.

Mazioti, A.A., Stasinakis, A.S., Gatidou, G., Thomaidis, N.S., Andersen, H.R., 2015. Sorption and biodegradation of selected benzotriazoles and hydroxybenzothiazole in activated sludge and estimation of their fate during wastewater treatment. Chemosphere 131, 117-23.

Mazioti, A., Stasinakis, A.S., Pantazi, Y., Andersen, H.R., 2015. Biodegradation of benzotriazoles and hydroxy-benzothiazole in wastewater by activated sludge and moving bed biofilm reactor systems. Bioresour. Technol. 192, 627-635.

Muz, M., Ak, S., Komesli, O.T., Gokcay, C.F., 2014. Removal of endocrine disrupting compounds in a lab-scale anaerobic/aerobic sequencing batch reactor unit. Environ. Technol. (United Kingdom) 35, 1055-1063.

Ødegaard, H., 1999. The Moving Bed Biofilm Reactor. Water Environ. Eng. Reuse Water 250-305.

Oehmen, A., Keller-Lehmann, B., Zeng, R.J., Yuan, Z., Keller, J., 2005. Optimisation of poly- $\beta$ hydroxyalkanoate analysis using gas chromatography for enhanced biological phosphorus removal systems. J. Chromatogr. A 1070, 131-136.

Ogunlaja, O.O., Parker, W.J., 2018. Modeling the biotransformation of trimethoprim in biological nutrient removal system. Water Sci. Technol. wst2018098.

Pastorelli, G., Canziani, R., Pedrazzi, L., Rozzi, A., 1999. Phosphorus and Nitrogen Removal in Moving-Bed Sequencing Batch Biofilm Reactors. Water Sci. Technol. Polesel, F., Andersen, 
H.R., Trapp, S., Plósz, B.G., 2016. Removal of antibiotics in biological wastewater treatment systems - A critical assessment using the Activated Sludge Modelling framework for Xenobiotics ( ASM-X ). Environ. Sci. Technol. 50, 10316-10334.

Piculell, M., 2016. New Dimensions of Moving Bed Biofilm Carriers: Influence of Biofilm Thickness and Control Possibilities. PhD Thesis. Department of Chemical Engineering, Lund University.

Polesel, F., Torresi, E., Loreggian, L., Casas, M.E., Christensson, M., Bester, K., Plósz, B.G., 2017. Removal of pharmaceuticals in pre-denitrifying MBBR - Influence of organic substrate availability in single- and three-stage configurations. Water Res. 8

Radjenović, J., Petrović, M., Barceló, D., 2009. Fate and distribution of pharmaceuticals in wastewater and sewage sludge of the conventional activated sludge (CAS) and advanced membrane bioreactor (MBR) treatment. Water Res. 43, 831-41.

Reemtsma, T., Weiss, S., Mueller, J., Petrovic, M., González, S., Barcelo, D., Ventura, F., Knepper, T.P., 2006. Polar Pollutants Entry into the Water Cycle by Municipal Wastewater: A European Perspective. Environ. Sci. Technol. 40, 5451-5458.

Santos, S.G., Zaiat, M., Varesche, M.B., Foresti, E., 2001. Comparative research on the use of methanol, ethanol and methane as electron donors for denitrification 61-68.

Stoquart, C., Vázquez Rodríguez, G.A., Servais, P., Sauvé, S., Barbeau, B., 2016. Micropollutant Removal Potential by Aged Powdered Activated Carbon. J. Environ. Eng. 4016058.

Suarez, S., Lema, J.M., Omil, F., 2010. Removal of Pharmaceutical and Personal Care Products ( PPCPs ) under nitrifying and denitrifying conditions. Water Res. 44, 3214-3224.

Tang, K., Ooi, G.T.H., Litty, K., Sundmark, K., Kaarsholm, K.M.S., Sund, C., Kragelund, C., Christensson, M., Bester, K., Andersen, H.R., 2017. Removal of pharmaceuticals in conventionally treated wastewater by a polishing moving bed biofilm reactor (MBBR) with 
intermittent feeding. Bioresour. Technol. 236, 77-86.

Ternes, T.A., 1998. Occurrence of drugs in German sewage treatment plants and rivers. Water Res. 32, $3245-3260$.

Torresi, E., Fowler, J.S., Polesel, F., Bester, K., Andersen, H.R., Smets, B.F., Plosz, B.G., Christensson, M., 2016. Biofilm thickness influences biodiversity in nitrifying MBBRs Implications on micropollutant removal. Environ. Sci. Technol. 50, 9279-9288.

Torresi, E., Casas, M.E.C., Polesel, F., Pl, B.G., Bester, K., 2017a. Impact of external carbon dose on the removal of micropollutants using methanol and ethanol in post-denitrifying moving bed biofilm reactors $108,95-105 . \mathrm{d}$

Torresi, E., Polesel, F., Bester, K., Christensson, M., Smets, B.F., Trapp, S., Andersen, H.R., Gy, B., Plosz. 2017b. Diffusion and sorption of organic micropollutants in biofilms with varying thicknesses. 123, 388-400.

Vieno, N., Sillanpää, M., 2014. Fate of diclofenac in municipal wastewater treatment plant - A review. Environ. Int. 69, 28-39.

Zhou, Y., Pijuan, M., Zeng, R. J., Lu, H., \& Ã, Z. Y. (2008). Could polyphosphate-accumulating organisms ( PAOs ) be glycogen-accumulating organisms ( GAOs )?, 42, 2361-2368.

Wang, Y., Geng, J., Ren, Z., He, W., Xing, M., Wu, M., Chen, S., 2011. Effect of anaerobic reaction time on denitrifying phosphorus removal and N2O production. Bioresour. Technol. 102, 56745684.

Wang, X., Oehmen, A., Freitas, E. B., Carvalho, G., \& Reis, M. A. M. (2017). The link of feast-phase dissolved oxygen (DO) with substrate competition and microbial selection in PHA production. Water Research, 112, 269-278. 


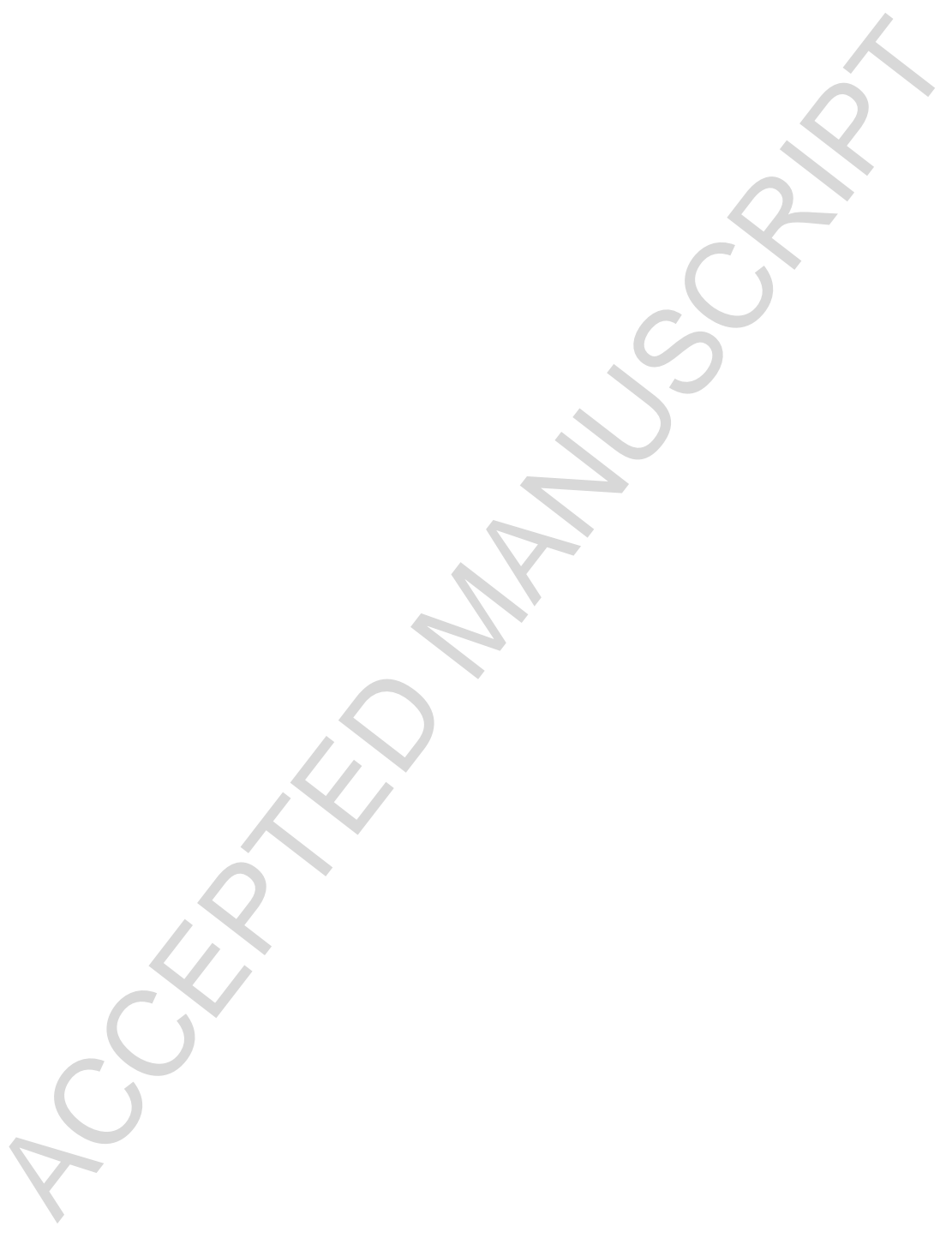




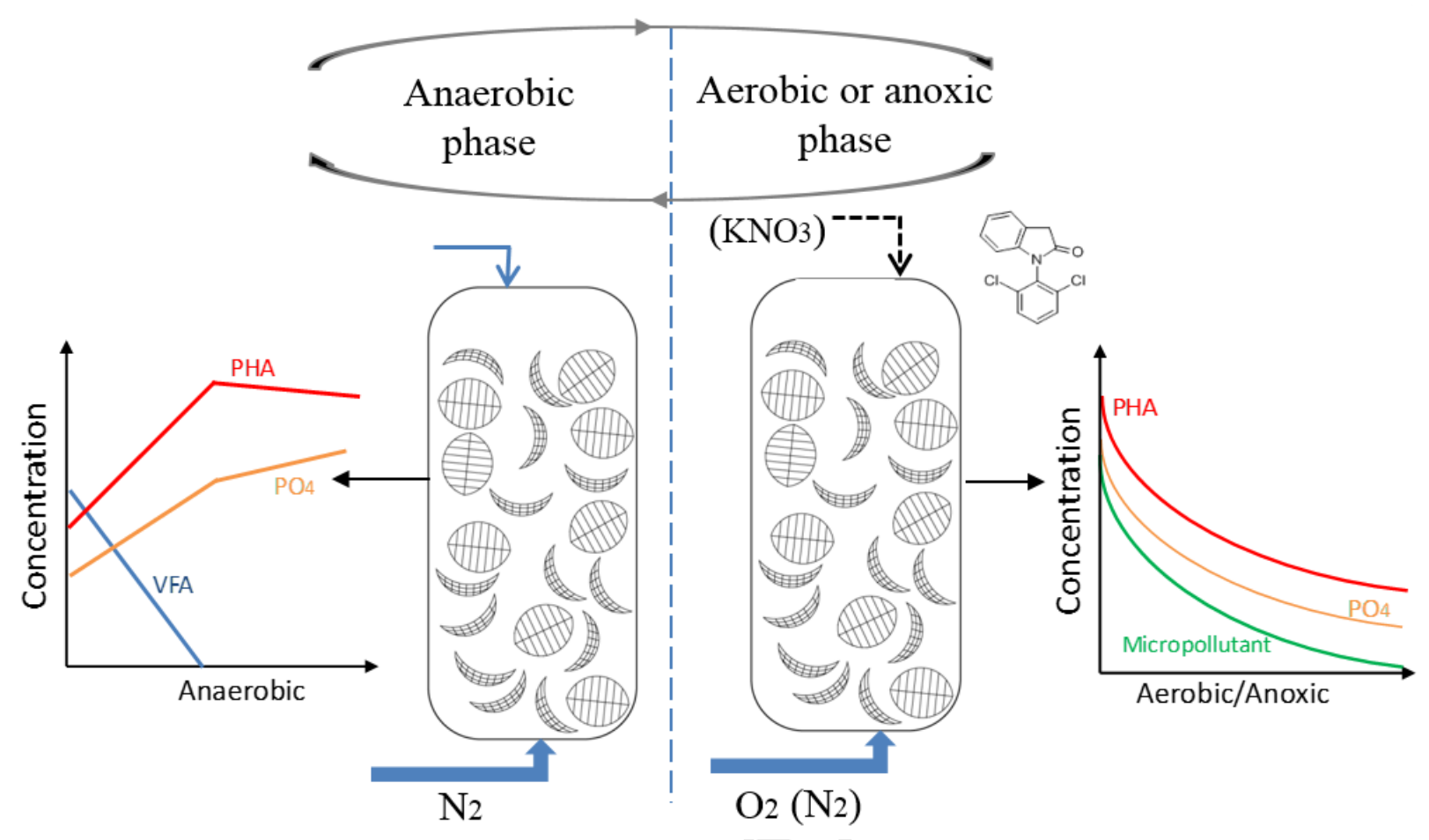

Graphical abstract 


\section{Highlights}

- MBBR operated for biological phosphorus removal under different redox conditions

- Aerobic PAO efficiently removed nine targeted micropollutants

- Removal occurred simultaneously to phosphorus uptake for several micropollutants

- Denitrifying PAO and GAO exhibited lower removal than aerobic PAO

- $\quad$ PHV and PHB contributed differently to removal of phosphorus and micropollutants 